\title{
El señorío de Villafranca de la Sierra, una concesión temprana *
}

\author{
The lordship of Villafranca de la sierra: an early grant
}

\author{
José Adolfo ReViejo PaZ**
}

\begin{abstract}
RESUMEN
Alfonso X, obligado por necesidades repobladoras, hace merced por los servicios prestados a Esteban Domingo, alcalde de Ávila, del señorío jurisdiccional de Villafranca. Pocos meses después, Esteban

Domingo, conforme a la jurisdicción otorgada por el rey, concede una carta puebla al concejo, delimitando el territorio donde ha de ejercer el señorío, además de establecer la fiscalidad y la justicia a seguir con la finalidad de incrementar la población

del territorio. Por último, establece las

condiciones sucesorias en el señorío, conformando la institución de mayorazgo, buscando el aseguramiento de las rentas.

Privilegios que posteriormente serán confirmados a sus descendientes por los monarcas sucesivos.
\end{abstract}

\section{PALABRAS CLAVE}

Alfonso X; Esteban Domingo; Blasco Muñoz; señorío territorial; señorio jurisdiccional; mayorazgo; repoblación.

\section{ABSTRACT}

Alfonso $X$, driven by a need to repopulate his domain, bestowed upon Esteban Domingo, judge of Avila, jurisdictional lordship over Villafranca. A few months later, Esteban Domingo, in accordance with the authority granted to him by the king, issued a town charter defining the territorial limits of his lordship and establishing laws and fiscal regulations in order to foment the population of the domain. Finally, he established a system of inheritance rights for the eldest male of his lineage, the privilege of mayorazgo, in order to avoid the dispersal of rents from generation to generation. These privileges would later be confirmed to his descendants by future kings.

\section{KEY WORDS}

Alfonso X, Esteban Domingo, Blasco Muñoz, territorial lordship, jurisdictional lordship, mayorazgo, repopulation of territories.

* Fecha de recepción del artículo: 2012-11-19. Fecha de aceptación del artículo: 2013-2-28.

** DEA en Historia Medieval y doctorando en el Departamento de $\mathrm{H}^{\mathrm{a}}$ Medieval y Ciencias y Técnicas Historiográficas de la UNED. C.e.: jreviejoadol@terra.es. 


\section{INTRODUCCIÓN}

La referencia más antigua sobre el señorío de Villafranca de la Sierra, conocido como Villafranca de Corneja en la Edad Media, se corresponde con la concesión del mismo en un diploma expedido en la ciudad de Soria de fecha 26 de abril de 1256 por el rey Alfonso X el Sabio, otorgando merced a Esteban Domingo de Ávila del citado señorío y delimitando su alcance, «... con todo su término de somo del puerto de Corneia ... ${ }^{1}$, por los muchos servicios prestados, conformándose así como I señor de Villafranca. Caballero abulense, el cual venía desempeñando puestos de responsabilidad pública en la ciudad como alcalde de Ávila², al igual que su padre, Blasco Muñoz, el adalid llamado el Soberbioso ${ }^{3}$, abuelo, Esteban Domingo, y su hijo y sucesor, Blasco Muñoz — lo que indica el carácter vitalicio y hereditario de los cargos públicos en el concejo abulense- había participado activamente en la conquista de la Andalucía Bética, distinguiéndose en el cerco de Jaén formando parte de la hueste de Fernando III junto a su hermano Blasco Blázquez, caudillo y capitán de las compañías abulenses ${ }^{4}$. Posteriormente al servicio de Alfonso X, fue premiado por su lealtad con la concesión del dicho lugar de Villafranca de la Sierra, segregándolo de la extensísima Tierra de la ciudad de Ávila. Tal concesión supone una característica un tanto peculiar, pues conllevaba, sin duda alguna, la jurisdicción plena sobre Villafranca y su tierra con la única limitación del pago al rey de la «moneda forera», condiciones y límites que aparecen en dicho privilegio ${ }^{5}$.

1 Archivo Ducal de Medinaceli, en adelante, ADM. Secc. Villafranca, Leg. 1, doc. 1; También ADM. Secc. Villafranca, Leg. 1, doc. 2, (en traslado de 1707). Cabe señalar que el regesto facilitado por el inventario del Partido de Villafranca en el citado archivo (por Manuel Antonio Brochero, año de MDCCXXXXII), equivoca el día de la fecha de donación, exactamente escribe: «Merçed que hizo el rey don Alfonso en Soria a 31 de abril, hera de 1294, que es año del nacimiento de nuestro redemptor de 1256, a Estevan Domingo de Ávila, de Villafranca con todo su término de somo del puerto de Corneja». Ver MARÍN RAMÍREZ, J. A. Los Dávila: señores de Villafranca y Las Navas en la Baja Edad Media, (Tesis doctoral s. p.), Facultad de Filosofía y Letras de la Universidad de Cádiz, 1997, pg. 51; tesis doctoral que no he podido consultar, pero obtengo la referencia de FRANCO SILVA, A. en "Señoríos y Ordenanzas en tierras de Ávila: Villafranca de la Sierra y Las Navas", Fuentes históricas abulenses, $n^{\circ} 70$, Fundación «Gran Duque de Alba», Ávila, 2007; debo hacer notar que las signaturas documentales que ofrece este autor son equivocadas, pues hace referencia a la signatura antigua, habiendo sido reformado el referido fondo recientemente. También vid. LUIS LÓPEZ, Carmelo, «Otros señoríos de los sectores central y septentrional», en Historia de Ávila IV, Edad Media (S. XIV-XV), Ávila, Institución «Gran Duque de Alba», 2009, pp. 262-263. Por otro lado, vid. MOZO CILLERO, C. Villafranca de la Sierra, sus hombres y sus tierras. Avila, 2001, pp. 35-36.

2 Sección Nobleza del Archivo Histórico Nacional, en adelante SNAHN, Secc. Parcent, C. 123, doc. 30.

3 Ibídem. ARIZ, Fray Luis de., $H^{a}$ de las grandezas de la ciudad de Ávila, ed. facsímil, Ávila, 2008, IV parte, fol. 2. La información de este autor sobre la familia a veces es errónea, especialmente en las fechas proporcionadas, a pesar de ser exhaustiva.

4 SNAHN, Secc. Parcent, C. 123, doc. 30. ARIZ, Fray Luis de., $H^{a}$ de las grandezas..., op. cit. pg. , III parte, fol. 15. MARTÍNEZ DÍEZ, G., Fernando III, Palencia, 1993, pp. 185 y ss. Crónica de la población de Ávila., Ed. HERNÁNDEZ SEGURA, A., Valencia, 1996, pp. 42-44. MARTín CARRAMOLINO, J., $H^{a}$ de Ávila, su provincia y obispado. T. II. Ed. facsímil, Ávila, 1999, pp. 348-350.

${ }_{5}$ ADM. Secc. Villafranca, Leg. 1, doc. 1; y doc. 2, (En traslado de 20 de julio de 1707, por Simón López de Sobrado, escribano del rey). 
Poco tiempo después, en nuevo diploma de fecha 25 de agosto de dicho año, Esteban Domingo, I señor de Villafranca, otorga una carta puebla en Villafranca, estableciendo los límites territoriales, la fiscalidad a seguir, la cuestión de la justicia a aplicar por la comisión de determinados delitos, y por último, determina las condiciones de sucesión en el señorío ${ }^{6}$.

Seguidamente, otro documento de fecha 25 de mayo de 1260, estando al frente de la herencia de su padre Esteban Domingo, Blasco Muñoz, II señor de Villafranca, confirma el mayorazgo familiar, donde se constata que Esteban Domingo murió al parecer en el año 1260, antes del 25 de mayo:

«Et yo, Blasco Munnoz, fiio de Esteuan Domingo el sobredicho, que finqué en Villafranca en lugar de don Esteuan Domingo, mi padre, vy este preuillejo que sobre dicho es, que do don Esteuan Domingo, mi padre, de Áuila ... Et a saluamiento del alma de don Esteuan, mío padre. Et yo, Blasco Munnoz, confírmolo e otórgolo ... Feta carta, seys días por andar del mes de mayo en la era de mill e dozientos e nouaenta e ocho annos.»?

Pero además, en su incompleto testamento de fecha 7 de mayo de $1261^{8}$ se hace referencia expresa a su deceso antes de su definitiva redacción, por lo que se debió terminar por el propio cabildo de Ávila, al que otorgó numerosas donaciones a cambio de su enterramiento en la iglesia catedral en la capilla de San Miguel, por su hijo Blasco Muñoz y por sus albaceas:

«Esto todo que aquí recontado es, fue fecho en vida de don Estevan Domingo. E porque la carta non se vido ${ }^{9}$ fazer, depués el cabildo e Blasco Munnoz, que fincó

\footnotetext{
${ }^{6}$ Archivo Real Chancillería de Valladolid, en adelante, ARCHV, Pergaminos, Carp. 17, doc. 9 (En traslado inserto de 30-IV-1350); se trata de una carta puebla inserta en un traslado de un privilegio a favor de Blasco Muñoz de fecha 26-V-1260, inserto a su vez en otro traslado de fecha 4-I-1316 y firmado por el escribano Domingo Muñoz, inserto en otro traslado de fecha 30-IV-1350 y realizado en la ciudad de Ávila por el escribano Alfonso Méndez y a petición de Esteban Domingo el Mozo; Ed. TELLERÍA ORBELZU, A. Ma․ «El señorío de Villafranca de la Sierra en Ávila: dos diplomas medievales en el Archivo de la Real Chancillería de Valladolid», Edad Media 2001, pp. 230-232. También ADM. Secc. Villafranca, Leg. 1 , Doc. 2, (En traslado del siglo XVI, y otro del siglo XVIII). Vid. LUIS LÓPEZ, Carmelo, "Otros señoríos de los sectores central...». Op. cit. pg. 266; y FRANCO SILVA, A., "Señoríos y Ordenanzas en tierra de Ávila...» Op. cit. pg. 16-17.

7 ARCHV, Pergaminos, Carp. 17, doc. 9 (25-V-1260, en traslado inserto de 30-IV-1350); ADM. Secc. Villafranca, Leg. 1, Doc. 2. (Traslado del siglo XVI, y otro del siglo XVIII). Monsalvo Antón confunde la fecha de su deceso, señalando su muerte en 1261, «El realengo y sus estructuras de poder», en $H^{a} d e$ Ávila III. Edad Media. (Siglos XIV-XV), Ávila, Institución «Gran Duque de Alba», 2006, pg. 111. Por su parte, LUIS LÓPEZ, C. sitúa su muerte antes del 6 de mayo de 1260, "Otros señoríos de los sectores central...", op. cit. pg. 272, confundiendo la data de dicho documento por la real de 25 de mayo de 1260 , según prueba el documento referido.

${ }_{8}$ Archivo Histórico Nacional, en adelante, AHN. Secc. Clero. Pergaminos. Carp. 20, no 11. Ed. Barrios García, A. «Documentos de la Catedral de Ávila (Siglos XII-XIII)», Fuentes Históricas Abulenses, ㄲo 57. Ávila, Institución «Gran Duque de Alba», doc. 99, pp. 183-187.

9 Ibídem; Ángel Barrios comenta que en el documento está escrito «vivo", sobre lo que creo que no hay duda; por su parte, Carmelo Luis transcribe por "pudo", lo que tiene más lógica, "Otros señoríos de los sectores central...». Op. cit. pg. 272.
} 
en voz de don Estevan Domingo, con todos los otros herederos de don Estevan Domingo de suso dichos, acabáronlo e fiziéronlo poner en escripto en esta carta»

En dicho testamento, figura además que tales concesiones al cabildo responden a que era canónigo y compañero del mismo:

«... e en salvamiento de mi alma, por mucha ondra e graçia muy grande e por mucho bien que reçebí en mi vida, seyendo canónigo e conpanno. Do al cabildo dela sobredicha eglesia ...»

Al poco, el rey Alfonso X confirma, a petición de Blasco Muñoz, una sentencia dada por el alcalde de la Mesta, Rui Fernández, en la que declara que el término de Villafranca es dehesa de labor, prohibiendo a los ganaderos de la misma entrar en la dicha dehesa con sus ganados y cortar madera para sus carretas sin permiso del titular del señorío. El deslinde del mismo refleja que comprende todo el término de Villafranca, quedando acotado todo el territorio ${ }^{10}$.

Posteriormente, en el año 1302, Fernando IV confirma las mercedes otorgadas por su abuelo Alfonso X, su padre Sancho IV y las propias concedidas por él mismo, declarando no pertenecerle a él ni a sus progenitores cualquier derecho, pecho ni justicia en Villafranca, y si la «moneda forera» le perteneciera, hacía gracia de ella a Esteban Domingo, hijo de Ibáñez Esteban y nieto de Esteban Domingo, el alcalde de Alfonso X, a resultas de la repoblación que hizo al otorgar la Carta Puebla citada ${ }^{11}$.

Poco tiempo después, el infante don Pedro, hijo de Sancho IV y de la reina doña María de Molina, como tutor de su sobrino Alfonso XI, y junto a su madre, confirman a Blasco Muñoz, hijo de Sancho Esteban y nieto del fundador Esteban Domingo, la villa de Villafranca con todos los derechos inherentes a la misma, así como el propio Alfonso XI, debido a que por la minoría de edad de Blasco Muñoz, le había sido usurpada su herencia por algunos parientes ${ }^{12}$.

Para terminar, el llamado Pleito de Villafranca determina la ordenación del señorío hecha por Esteban Domingo el Viejo ${ }^{13}$, mediante la concesión de fuero o

10 ADM. Secc. Villafranca, Leg. 1, Doc. 3.

11 ADM. Secc. Villafranca, Leg. 1, Doc. 4; y Doc. 2 (Traslado del siglo XVIII). Ed. por MOZO CILLERO, C. Villafranca de la Sierra..., op. cit., pp. 37-38; y ed. en parte por LUIS LÓPEZ, Carmelo, «Otros señoríos de los sectores central...». Op. cit. pg. 275.

12 ADM. Secc. Villafranca, Leg. 1, doc. 5, y doc. 18; además en ADM. Secc. Villafranca, Leg. 1, doc.2 (Traslados del siglo XVIII) y doc. 8. (Copia impresa del siglo XVIII sobre traslado inserto en fecha 1389, marzo, 19); por último ARCHV, Pergaminos, Carpeta, 17, 10. (En traslado inserto en fecha 1389, marzo, 19).

13 SNAHN, Secc. Parcent, C. 123, doc. 30. Esteban Domingo, el fundador del señorío, fue llamado «el Viejo» y, casado con doña Garoza o Gracia, como aparece en otros documentos, tuvo cuatro hijos y dos hijas: Blasco Muñoz, primogénito y heredero, será el II señor de Villafranca; Ibáñez Esteban, segundo hijo y padre de Esteban Domingo, IV señor de Villafranca; Sancho Esteban, que después fue conocido como Esteban Domingo, será III señor de Villafranca, y fue el padre de Blasco Muñoz, V señor de Villafranca; su cuarto hijo será don Mateos Dávila, padre del VI señor de Villafranca, Gonzalo González; sus hijas serán Dominga Gómez y Amuña Esteban. Carmelo Luis López identifica como Esteban 
carta puebla mencionada más arriba, disponiendo para sus herederos la vinculación de las rentas del señorío o iniciando la institución de mayorazgo, lo que supone otra prerrogativa jurídica que vendrá a confirmar el grado jurisdiccional que poseía el fundador del señorío por merced real ${ }^{14}$.

Tales documentos serán sujetos a estudio en el presente trabajo para establecer y analizar el grado jurisdiccional del señorío de temprana concesión, así como el establecimiento de mayorazgo. La cuestión es clarificar la complejidad que ofrece su génesis y determinar la existencia del grado evolutivo de una estructura feudal en el territorio de Villafranca a través de los documentos presentados, caracterizando la propiedad feudal, punto clave para conocer tal estructura. Para establecerla, se requiere una clara matización de los términos contenidos en los dichos documentos atendiendo a la consumación que para el feudalismo representó la formación de señoríos, es decir, se trata de determinar el porqué de la concesión del señorío jurisdiccional pleno sin conllevar el proceso natural evolutivo que presenta el desarrollo del dominio señorial ${ }^{15}$. Proceso en el que la monarquía tuvo un papel relevante, y sobre todo en la zona sur del Duero, donde el proceso fue muy diferente a la parte norte, surgiendo desde finales del siglo XII, una nueva modalidad repobladora: la intervención monárquica, concretada en la concesión de fueros mediante un pacto con la entidad receptora del mismo, el concejo, constituyéndose en una realidad económica, social y política, pero siempre reconociendo la autoridad o dependencia del monarca, la cual se inscribe en la estructura política feudal ${ }^{16}$; así, se articularía, y dentro de este marco, el concejo como señorío colectivo, lo que no implica que la fijación de su demarcación jurisdiccional fuera estable, pues el monarca hizo en numerosas ocasiones ciertas segregaciones en estos concejos de realengo a favor de la aristocracia laica o eclesiástica, a favor de otros concejos, o a favor de un linaje local dominante ${ }^{17}$, caso éste último en el que nos vamos a centrar. Por otro lado, la propia evolución de la institución señorial incrementó las inmunidades jurisdiccionales con prerrogativas o facultades de carácter tributario, administrativo y judicial; estas faculta-

Domingo el Viejo al III señor de Villafranca, manteniendo que fue el hijo menor de Esteban Domingo, el fundador, «Otros señoríos de los sectores central...». Op. cit. pg. 274.

14 ARCHV, Pergaminos, Carp. 17, doc. 10; ADM. Secc. Villafranca, Leg. 1, doc. 2 y doc. 8 (Copias impresas del siglo XVIII). Este documento no lo vamos a incorporar al anexo documental posterior por ser muy extenso; para ello baste señalar las referencias al mismo y los extractos del documento que vienen al caso que tratamos.

15 ESTEPA DÍEZ, C. «Formación y consolidación del feudalismo en Castilla y León», en En torno al feudalismo hispánico, I Congreso de Estudios Medievales, Fundación Sánchez Albornoz, Ávila, 1989, pp. 157-256. Dicho autor mantiene el proceso lógico de formación, estableciendo la cadena propiedad dominical, domino señorial y señorío jurisdiccional, como signo claro evolutivo.

16 MÍNGUEZ FERNÁNDEZ, J. Mª ., Las sociedades feudales, I, Nerea, 1994, pp. 295-297.

17 BONACHÍA HERNANDO, J. A., «El concejo como señorío (Castilla, siglos XIII-XV)», en Concejos y ciudades en la Edad Media Hispánica, II Congreso de Estudios Medievales, Fundación Sánchez Albornoz, 1990, pp. 434-435. Como ocurrió en el territorio del concejo abulense, al que los monarcas desmembraron masivamente entre los años 1231-1310; BARRIOS GARCÍA, A., Estructuras agrarias y de poder en Castilla: el ejemplo de Ávila. 1085-1320, vol. 2, Institución “Gran Duque de Alba», Ávila, 1984, pg. 162. 
des, a su vez, implican el ejercicio de la jurisdicción como una extensión privilegiada del dominio sobre la tierra, cuya adscripción al titular del señorío se consolida con la institución de mayorazgo, institución que generalizó la transmisión indivisa de estos privilegios a sus sucesores, garantizando la integridad de la herencia señorial mediante la posibilidad de establecer la línea de sucesión por vía lateral en caso de fallar la directa, vinculando las rentas señoriales ${ }^{18}$. Por lo tanto, se requiere una explicación sobre las condiciones fundacionales del mayorazgo, y la formación del mismo por Esteban Domingo de Ávila, pues la concesión del señorío y la constitución de dicho mayorazgo, llaman la atención sobre la temprana fecha del hecho.

La presentación del consiguiente corpus documental obedece a que todos corroboran el primer documento dado por Alfonso X a Esteban Domingo, concediendo merced con plena jurisdicción señorial.

\section{SEÑORÍO TERRITORIAL - SEÑORÍO JURISDICCIONAL}

Tras la reconquista y repoblación de la Extremadura castellana, quedaron extensos espacios yermos debido a su infertilidad y al rápido avance militar hacia el sur en los siglos XII y XIII, amén de las limitaciones demográficas. Los reyes, en especial, Alfonso X, conscientes de la necesidad de colonización de estos parajes, y atendiendo a los servicios prestados por sus colaboradores, deseosos de recompensarles, les atribuirán mediante donación estos territorios. En el caso que nos ocupa, cuando la zona sujeta a donación se encuentra dentro de un término concejil atribuido a una ciudad, la concesión del privilegio se efectuará al amparo del derecho de soberanía, lo que podría iniciar conflictos entre el poder central y el municipal. Sin embargo, el concejo abulense, incapaz de llevar a cabo otro tipo de colonización en estos lugares, secundó la política real concediendo paralelamente, e incluso a veces antes que el propio rey, la donación del territorio. Política que supondrá, además del encumbramiento de determinados linajes, la intromisión de la nobleza en la Extremadura castellana, zona de fuerte arraigo concejil, cuyo horizonte dominical se reservaba a las Órdenes Militares y a la Mitra toledana ${ }^{19}$. No obstante, el problema que planteamos es el origen del patrimonio de los Dávila ${ }^{20}$ y la concesión de señorío en Villafranca de la Sierra a Esteban Domingo, iniciador del linaje de una de sus ramas, conforme a la documen-

18 El mayorazgo quedó institucionalizado jurídicamente en las Cortes de Guadalajara de 1390.

19 MOXÓ, S. de., "La nobleza castellana en el siglo XIV», en Anuario de Estudios Medievales, 7 (1970-1971), pg. 502.

20 Nosotros sólo nos ocuparemos del linaje de Esteban Domingo. Para ver el linaje de Blasco Ximeno, y los señoríos de Velada, Navamorcuende, Villatoro y San Román, remito a MORENO NÚÑEZ, J. I., «Los Dávila, linaje de caballeros abulenses. Contribución al estudio de la nobleza castellana en la Baja Edad Media", en Estudios en memoria del profesor D. Salvador de Moxó, II. UCM., 1982, pp. 157-172. Del mismo autor hacemos notar su obra Ávila y su tierra en la Baja Edad Media. S. XIII-XV, Junta de Castilla y León, 1992; y sobre todo su cap. III «La señorialización de la tierra de Ávila», pp. 73-126, donde realiza 
tación aportada. La intervención de la familia en la reconquista y el ejercicio de ciertos cargos políticos y burocráticos determinaron que sus miembros, los más prominentes, fueran recompensados por los monarcas mediante la concesión de tierras y jurisdicción. La concesión de estos privilegios a favor del estamento caballeresco, junto a la concesión de privilegios territoriales, marcará la vertebración institucional y jurídica del territorio abulense. No hay que olvidar que la caballería villana consiguió, y en este caso Esteban Domingo de Ávila, centralizar el poder sobre la tierra y los hombres de una doble manera: delimitando el territorio o término donde ejercerá su jurisdicción y facilitando el asentamiento de pobladores a través de fueros o cartas pueblas, constituyéndose ambos supuestos en rasgos estructurales como resultado del carácter feudal que matiza la organización del territorio. El caso que nos ocupa, la formación del señorío de Villafranca o el origen del patrimonio de Esteban Domingo, está estrechamente ligado a la repoblación tardía de determinadas zonas del alfoz de Ávila. Pero de dicha repoblación nos ocuparemos más tarde. Ahora la cuestión es la fecha temprana de la concesión del señorío en los términos resaltados más arriba, es decir, la cesión de jurisdicción prácticamente un siglo antes del proceso generalizado por los Trastámara, especialmente durante el reinado de Enrique II, el cual supuso un importante cambio, primeramente por incrementar de forma notoria el número de concesiones señoriales, y en segundo lugar, por significar esencialmente concesiones jurisdiccionales sobre villas ${ }^{21}$. La concesión de la merced jurisdiccional, más propia de la Baja Edad Media, era común en la época sobre una villa o lugar ya organizado, donde el señor recibía la potestad jurisdiccional sobre sus nuevos vasallos y el dominio solariego sobre el territorio previamente habitado, cuya fórmula cancilleresca de concesión reza con monotonía «con la jurisdicción civil e criminal, alta e baja, e mero e mixto imperio". Semejante cláusula no aparece en los documentos reseñados, hay que entender que dicho formulario obedece ya a la Baja Edad Media, y en la segunda mitad del siglo XIII se puede comprender la falta de concreción documental en la concesión de tales mercedes, por lo que el deslinde de las facultades solariegas y jurisdiccionales se presenta complicado debido a su fundición, sin embargo, sí se muestran los documentos muy ricos en términos semejantes, que de una u otra forma vienen a reseñar en muchos casos lo mismo. En resumen, atendiendo al caso que nos ocupa, la concesión señorial otorgada por el monarca, merced a los servicios prestados por el beneficiario, conlleva la plena facultad jurisdiccional sobre el lugar mediante las cláusulas del documento constitutivo, en el que contiene tanto el dominio solariego sobre el territorio como la potestad jurisdiccional sobre los vasallos que lo habitan, englobando la facultad de juzgar, y los derechos tributarios. Así, el gobierno del señorío

\footnotetext{
un sucinto estudio de los estados señoriales abulenses, mostrando diversas genealogías de las distintas ramas familiares de los Dávila.

${ }^{21}$ MONSALVO ANTÓN, J. Mํa ., La Baja Edad Media en los siglos XIV-XV. Política y cultura. Ed. Síntesis. Madrid, 2000, pg. 143. Este autor, además de insistir en la idea referida, nos facilita un numeroso elenco de autores que han investigado sobre el proceso de señorialización de Castilla en la época Trastámara, destacando entre otros Moxó, Valdeón, Quintanilla Raso, Franco Silva, Ladero, Mitre, etc, pp.141-177.
} 
queda formado atendiendo a diversos puntos: a través de sus relaciones con el concejo mediante los nombramientos de magistrados y oficiales, además del aprovechamiento de bienes comunales; las relaciones con los vasallos quedan señaladas mediante el control de la fiscalidad territorial, jurisdiccional y regaliana; y por último, el gobierno del señor, y sobre todo su facultad jurisdiccional, queda reflejado con dos prerrogativas de merced real, las facultades legislativas otorgando fueros o cartas pueblas y ordenanzas, y las facultades judiciales que conllevan la jurisdicción civil y criminal, además de los tribunales señoriales y la justicia del rey.

Un estudio pormenorizado de los documentos señalados concluye una serie de matizaciones que pueden aclarar lo expuesto. Me remito y hago hincapié en las cláusulas otorgadas y referidas en la carta de concesión real. Por este primer pergamino, el más antiguo de fecha 26 de abril de 1256, el rey don Alfonso X establece los límites y condiciones de la merced dada. La causa de tal otorgamiento es «Por los muchos seruiçios que me fizo Esteuan Domingo de Áuila, mío alcalde ...», donde encontramos el motivo ya apuntado por el que se contiene el deseo por parte del monarca para hacer la donación y merced. Además, remarca el término territorial concedido, delimitando el alcance al que debe regirse la acción jurisdiccional del titular, no suponiendo más que la delimitación geográfica que representa el área jurisdiccional del alcance el señorío:

"Connosçuda cosa sea a todos los omnes que esta carta vieren, cónmo yo, don Alfonso, por la graçia de Dios, rey de Castiella, ..., por los muchos seruiçios que me fizo Esteuan Domingo de Áuila, mío alcalde, dol e otórgol a Villafranca con todo su término de somo del puerto de Corneia conmo ua a las Cabeças del Ortigal; e dél dende a la Garganta de los Fornos, así conmo naçen e vierten las aguas a Corneia; e dél dende a somo del puerto de Vichía; e dél dende a la Garganta del Ortigal, así conmo corren las aguas a Corneia; e dende a somo de la Garganta de Garuenna, e Garuenna [ayuso] así conmo caen en Corneia; e de la otra parte de somo del Puerto de Corneia, así conmo nasçe el arroyo del puerto ayuso por oriella de Voniella; e el arroyo ayuso fa[s]ta que cae en Corneia.» ${ }^{22}$

Primeramente, cabe señalar el propio nombre del término «Villafranca», el cual nos refleja a las claras su carácter de franqueza, de villa exenta, donde podemos incluir cualquier exención de tipo fiscal y una total cesión jurisdiccional en todos los términos, puesto que la sóla definición conlleva plenos poderes. La misma cuestión de "villazgo» conlleva y es consubstancial a la concesión de competencias jurisdiccionales, es decir y sobre todo, a la justicia civil y criminal, alta e baja, mero e mixto imperio. Por lo tanto, la concesión del referido señorío no puede obedecer a una estructura evolutiva de dominio señorial - señorío jurisdiccional, puesto que conforme a la necesidad de repoblación tardía, de la que

${ }^{22}$ ADM. Secc. Villafranca, Leg. 1, doc. 1; y doc. 2 (en traslado de 1707). Ed. MOZO CILLERO, C. Villafranca de la Sierra..., op. cit., pp. 35-37; y LUIS LÓPEZ, Carmelo, «Otros señoríos de los sectores central..., op. cit., pp. 262-263. 
nos ocuparemos más adelante, la zona territorial que nos ocupa no podía conformarse inicialmente como un dominio señorial, sino más bien, se configuraba como un despoblado dentro de la tierra y alfoz abulense, concejo de realengo, por lo que podemos afirmar con toda certeza que se constituyó en su origen como un señorío de nueva creación, previa concesión de «villa».

Seguidamente, atendiendo a la demarcación territorial que continúa, podemos establecer que se trata indudablemente de rentas de carácter territorial o solariego, donde el monarca tras justificar el motivo de la donación, realiza el deslinde jurídico del contorno territorial del señorío, otorgando a favor del beneficiario el aprovechamiento y disfrute del suelo, es decir, de sus rentas. Deslinde jurídico del territorio que posteriormente el propio beneficiario, Esteban Domingo, repite tras presentarse como siervo de su señor:

"Connosçida cosa sea a todos los omnes que esta carta vieren cónmo yo, Esteuan Domingo de Áuila, alcallde del rey, a seruiçio de Dios e Santa María e del rey don Alfonso, do a poblar a Villafranca con todo el término que yo he desdel somo del Puerto de Sanchández ${ }^{23}$ así conmo parten con los de Voniella e fiere en Corneia, e dela otra parte a somo de Serrota conmo vierten las aguas a Corneia; et dende a somo dela Garganta delos Fornos, e dende a somo del puerto de Vechía así conmo las aguas vierten en Corneia, e dende Açeruunal loco, así conmo las aguas vierten en Corneia; e dende a somo la Garganta de Garuenna conmo las aguas vierten en Corneia; et Garuenna ayuso conmo fiere en Corneia» ${ }^{24}$.

Esteban Domingo establece el término territorial que la merced de su señor el rey le ha otorgado, pero con ciertas matizaciones, concretando aún más los linderos o límites territoriales, es decir establece, perfectamente delimitada, la administración territorial donde va a ejercer su jurisdicción señorial como se ha dicho. Acotamiento o deslinde territorial que posteriormente el rey Alfonso X confirma, a pedimento del hijo del dicho Esteban Domingo, Blasco Muñoz, en un diploma expedido en Burgos el 23 de septiembre de 1277, por una sentencia dada el 16 de mayo de dicho año sobre un pleito tratado por el alcalde de la Mesta, Rui Fernández, por la que se declara el señorío de Villafranca ser dehesa de labor, suponiendo la prohibición a los ganaderos de la Mesta de la entrada en la misma con sus ganados ${ }^{25}$ :

«Et yo uí el logar de la defesa que comiença por somo de los Foyos del Azeueda así conmo parten con los de Piedrafita e uierten las aguas a Corneia; et por somo del Çerbunal Longuiello así como uierten las aguas a Corneia; et por somo de los Foyos de Uelacha así conmo uierten las aguas a Corneia; et

23 Puerto de Villatoro.

24 ARCHV, Pergaminos, Carp. 17, doc. 9 (25-VIII-1256, en traslado inserto en 30-IV-1350); ADM. Secc. Villafranca, Leg. 1, doc. 2 (en traslado del siglo XVI y XVIII).

25 ADM. Secc. Villafranca, Leg. 1, doc. 3. Vid. LUIS LÓPEZ, Carmelo, «Otros señoríos de los sectores central...», op. cit. pg. 272; dicho autor equivoca la data del día, ofreciendo la fecha de 26. 
por somo del Puerto de Uechía así como uierten las aguas a Corneia; et por somo del Val de Serrota así como uierten las aguas a Corneia; et por somo de la Garganta del Uelesar conmo uierten las aguas a Corneia; et por somo de Val de Pasqual Munnoz conmo uierten las aguas a Corneia; et por somo de Maiada [de] Lança conmo uierten las aguas de Corneia; et por [somo] del Fortigal conmo uierten las aguas a Corneia; et por somo del Soto del Puerto de Sanchánder e por la carrera ayuso conmo da en las casas de don Viçeynte e conmo parten con Naualuenga».

Dicho deslinde coincidente con el término de Villafranca, suponía el acotamiento de todo el territorio y el alcance de un privilegio que conlleva, al ser todo el término declarado como coto reservado, la potestad de poder dedicar espacios para dehesas, montes y pinares para los vecinos, propiciando la repoblación de la villa y tierra, además de facilitar el cobro de impuestos por el paso de ganados pertenecientes a los forasteros, y reservar a los foráneos la facultad de circular libremente por el resto de las cañadas. Sentencia que confirma la plena potestad otorgada inicialmente sobre la totalidad del territorio y el aprovechamiento de sus rentas, es decir, la concesión de señorío solariego, al definir, por la demarcación dicha del territorio, la concesión de potestad sobre el mismo. Sin embargo, cabe entender ciertos derechos jurisdiccionales en el documento de concesión señorial, los cuales confirman el marco de la fiscalidad que puede el señor ejercer, tanto sobre foráneos como forasteros, y que corroboran la potestad señorial en la aplicación de dicha sentencia, al poder ser receptor de ciertos impuestos como hemos dicho. En otro orden, la defensa de los pastos del territorio y de los pasos de ganado trashumante, refleja la importancia de la ganadería como fuente de ingresos del señor, no siendo exclusivo del mismo, sino que se incluye en un proceso generalizado, por lo que sería más correcto expresarlo dentro de los intereses del estamento caballeresco ${ }^{26}$. En suma, la apropiación de tierras y aldeas, situadas en el paso de ganados por parte de la elite privilegiada de los caballeros, era significativa para la confirmación hegemónica de éstos ${ }^{27}$, bien desde el concejo o bien particularmente mediante concesiones regias.

Volviendo otra vez al problema que planteábamos al inicio, las diferentes fórmulas expresadas y analizadas en el documento de concesión, y sobre todo su diversidad, nos llevan a preguntarnos si la atribución de su poseedor supone solamente un señorío puramente solariego o por el contrario presupone la integra-

\footnotetext{
26 Numerosos conflictos enmarcados dentro de la defensa de los intereses ganaderos de los caballeros reflejan lo dicho: En la época de Alfonso VIII, mientras la población abulense se hallaba de procesión, los moros asaltaron la ciudad llevando muchos ganados, siendo recuperados por los caballeros tras cruzar el Valle Amblés camino de la sierra en la batalla de Barbazedo, dando nombre a la sierra; o cuando se repobló Ciudad Rodrigo en tiempos del rey Fernando II de León por ruanos huidos de Ávila al intentar compartir el poder con los serranos, los cuales robaron el ganado a los serranos abulenses, siendo interceptados por los mismos en Valdecorneja donde se les dio muerte. ARIZ, Fray Luis de., $H^{a}$ de las grandezas..., op. cit. pg. , III parte, fol. 5-6.

27 BARRIOS GARCÍA, A., Estructuras agrarias y de poder en Castilla: el ejemplo de Ávila. 1085-1320, vol. 2, Institución «Gran Duque de Alba», Ávila, 1984, pp. 148-149.
} 
ción de facultades jurisdiccionales. La diversidad existente en las «formas» y en el "contenido» del cuadro documental sugiere serias dudas necesarias de aclaración. No nos habla implícitamente de la concesión jurisdiccional, ni remarca los elementos que la constituyen, como la facultad de justicia criminal y civil, alta e baja e mero e mixto imperio. La cuestión es que la concesión real contiene términos muy precisos «E éstol do e le otorgo pora sí e pora quantos dél vinieren quelo ayan libre e quito, pora dar, pora vender, pora enpennar, pora camiar, pora enagenar, pora poblar, pora fazer dello todo lo que quisiere, saluo [ende], que me den a mí moneda» ${ }^{28}$. Términos que nos plantean la duda para determinar si podemos definir la concesión como señorí jurisdiccional o mediante la utilización de expresiones arcaicas de dominio solariego como mantenía Salvador Moxó ${ }^{29}$, pues el privilegio adolece de prácticamente todas la facultades inherentes a la complejidad jurisdiccional. El diploma no puede ser más parco, haciendo dudar de la naturaleza y tipología del señorío concedido. Ninguna mención de facultades jurisdiccionales, ni de transferencias de impuestos regios, pero sí a la retención del monarca de la moneda forera; lo que nos obliga a preguntarnos el porqué solamente la moneda y no los demás impuestos y servicios de índole pública, por lo que podemos concluir que ambas partes entendían que eran cedidos, pues de lo contrario quedarían señalados en el diploma. Quizás, la última parte «pora fazer dello todo lo que quisiere», suponga la transmisión al señor de las respectivas prerrogativas jurisdiccionales que hasta el momento correspondían al rey, además de llevar implícita la concesión de la justicia; por parte de ambos quedaba plenamente clara la subrogación de poderes, donde podemos incluir la concesión del privilegio de otorgar fuero con la expresión de «pora poblar", corroborado posteriormente al final de otro documento donde Esteban Domingo se erige con la potestad para realizar fuero «de mantenerlos a este fuero ${ }^{30}$. En otro orden, llama la atención que significara únicamente una concesión de señorío territorial cuando ya se aprecia un cierto predominio de elementos jurisdiccionales, no podemos olvidar que tratamos sobre una zona yerma y de escasa o ninguna población, alejada del centro administrativo abulense y por tanto difícil de controlar, cuestiones que podemos presuponer, aunque carecemos de una base documental firme.

La fiscalidad jurisdiccional, que deriva de la autoridad señorial y cuyo origen no se haya en el dominio del suelo sino en la general sumisión de los hombres en el señorío respecto al titular que ejerce la autoridad, anejas a su facultad gubernativa, se halla en el marco siguiente « $E$ éstol do e le otorgo pora sí e pora quantos dél vinieren que lo ayan libre e quito ... ${ }^{31}$; tal exención claramente define un

${ }^{28}$ ADM. Secc. Villafranca, Leg. 1, doc. 1, y doc. 2 (en traslado de 1707).

${ }^{29}$ MOXÓ, S. de., Los antiguos señoríos de Toledo. Inst. Provincial de Investigaciones y Estudios Toledanos. Toledo, 1973, pg. 43, not. 24.

${ }^{30}$ ARCHV, Pergaminos, Carp. 17, doc. 9 (25-VIII-1256, en traslado inserto en 30-IV-1350); ADM. Secc. Villafranca, Leg. 1, doc. 2 (en traslado del siglo XVI y XVIII).

${ }^{31}$ ADM. Secc. Villafranca, Leg. 1, doc. 1, y doc. 2 (en traslado de 1707). 
dominio señorial, incluso va más allá, otorgándose derechos jurisdiccionales que indican la formación de al menos un incipiente señorío jurisdiccional, puesto que con la propiedad, el beneficiario obtiene derechos señoriales, que por concesión regia de la inmunidad que otorga la cláusula «libre e quito» lleva implícita la jurisdicción en el lugar, exenciones tributarias y el ejercicio de poder político, es decir, privilegios, exenciones o inmunidades, que junto a la franquicia financiera supone una escasa injerencia del poder real en el señorío, donde el señor ejerce la fiscalidad jurisdiccional con mayor o menor amplitud. Supone en suma, no sólo el otorgamiento al señor de jurisdicción sobre el dominio sino la concesión de parte de los derechos y facultades de la potestad regia expresados seguidamente como «... pora dar, pora vender, pora enpennar, pora camiar, pora enagenar, pora poblar, pora fazer dello todo lo que quisiere ... ${ }^{32}$, de donde resulta de forma indudable, que además de atribuir la inmunidad, contiene una donación de derechos reales susceptibles de enajenación, continuando con la facultad de repoblación, elementos constitutivos de legítimo señorío jurisdiccional. Solamente presenta una única excepción «saluo ende, que me den a mí moneda» ${ }^{33}$, regalía que se reserva el monarca ante las necesidades de la cámara real. Por lo tanto, podemos presumir que la cesión de privilegios es total con esta única excepción, asumiendo que se le entrega pleno dominio sobre el territorio, así como plena jurisdicción señorial.

\section{LA CARTA PUEBLA DE VILLAFRANCA}

No obstante, las inmunidades o privilegios de que hablamos no quedan claramente reflejados en dicho documento como venimos manteniendo, debiendo sacar conclusiones para hacer validar la tesis que se defiende. Tales derechos no se mencionan explícitamente en el documento de donación, pero sí en la Carta Puebla dictada por el beneficiario pocos meses después de la concesión regia para comenzar el poblamiento de la villa, lo que no llegaría a culminar, pues cuatro años después, en 1260, Esteban Domingo falleció. Sin embargo, la Carta Puebla otorgada por Esteban Domingo como I señor de Villafranca, nos aclara la

\footnotetext{
32 ADM. Secc. Villafranca, Leg. 1, doc. 1, y doc. 2 (en traslado de 1707).

33 ADM. Secc. Villafranca, Leg. 1, doc. 1, y doc. 2 (en traslado de 1707). Clara referencia a la «moneda forera», impuesto creado ante la necesidad de los reyes de procurarse recursos con los que atender lo crecientes gastos del Estado. Cuando la hacienda se veía en apuros, los reyes recurrían a la «quiebra de la moneda», por la que conservando su valor nominal se acuñaba ésta con una aleación de metal más bajo, provocando graves trastornos económicos con el consiguiente alza de precios; los concejos, muy perjudicados por la "quiebra de la moneda», idearon el sistema de comprarle al rey su derecho de acuño arbitrando la facilitación de los recursos necesarios a la cámara real a cambio de que el rey se comprometiera a no acuñar moneda en un espacio de tiempo determinado, fijado en siete años; así la repetición de esta compra de moneda originó posteriormente que los súbditos sujetos a tributación satisficiesen al rey un impuesto, «moneda forera», cada siete años con la garantía de no "quebrar la moneda», llegando a tener carácter de ingreso ordinario del fisco. VALDEAVELLANO, Luis G. de., Curso de Historia de las Instituciones Españolas. De los orígenes al final de la Edad Media. Madrid, 1968, pp. 470-471 y 603 .
} 
cuestión. El hecho de otorgar fuero estableciendo, tras delimitar el territorio, las franquicias que concede a los autóctonos y futuros moradores del lugar, siguiendo la administración de la justicia con alcaldes propios, y una serie de exenciones fiscales y de servicios, suponen a nuestro entender la potestad facultativa de Esteban Domingo de un alto grado de jurisdicción. En suma, detenta capacidad administrativa, fiscal y judicial por lo que se puede mantener la afirmación dicha de concesiones jurisdiccionales. En dicha carta, primeramente vuelve al igual que el monarca, como ya se ha dicho, a establecer el ámbito y alcance territorial en el cual se va a ejercer la acción jurisdiccional, y siempre al amparo regio, para poblarla estableciendo fuero «Et yo Esteuan Domingo de Áuila, alcallde del rey, dógela a poblar, por mi alma a este fuero ...» ${ }^{34}$; claramente un privilegio no contenido en un señorío de carácter solariego, lo que encierra tanto prerrogativas administrativas, judiciales, fiscales o de cualquier tipo, o dicho de otra manera, se encuadra en el marco de funciones jurisdiccionales. En dicha Carta Puebla se contienen las reglas jurídico-legales que debían ser observadas por todo aquél que acudiera a poblar la villa:

"Que todos los pobladores que ý moraren destos seys annos, que non pechen; et de seys annos adelante, el que ouiere valía de quarenta marauedís, que peche un marauedí; et el que ouiere valía de treynta marauedís, peche tres quartas de marauedí; el que ouiere valía de veynte marauedís, peche medio marauedí; el que ouiere valía de diez marauedís, peche una quarta e non más.

Fueras, por yuntería e andadería, que pechen dos eminas, una çenteno e otra de çeuada cada anno por la [fiesta de] Sant Miguell e non más» ${ }^{35}$.

Tras establecer inicialmente los límites territoriales del señorío como se apuntó, Esteban Domingo exime de todo tipo de tributos señoriales a los villanos que moraren allí en un espacio temporal de seis años, en un intento de repoblar la exigua población que lo compone, posteriormente pagarían de acuerdo a su riqueza; además suprimía los servicios de «yuntería e andadería» ${ }^{36}$, cargas a las que estaban obligados los vasallos, prestaciones de servicios temporales de bueyes en las tierras del señor y de mensajeros o recaderos del mismo, a cambio de la entrega cada año a su señor por la fiesta de San Miguel (29 de septiembre) de dos heminas de grano, una de cebada y otra de centeno. En este caso, queda

\footnotetext{
${ }^{34}$ ARCHV, Pergaminos, Carp. 17, doc. 9 (25-VIII-1256, en traslado inserto en 30-IV-1350); ADM. Secc. Villafranca, Leg. 1, Doc. 2 (en traslado del siglo XVI y XVIII).

${ }^{35}$ ARCHV, Pergaminos, Carp. 17, doc. 9 (25-VIII-1256, en traslado inserto en 30-IV-1350); ADM. Secc. Villafranca, Leg. 1, Doc. 2 (en traslado del siglo XVI y XVIII).

${ }^{36}$ Aquí se constatan ciertos errores cometidos, al señalar los servicios referidos, por los autores más arriba señalados; errores que sin ninguna duda se deben a que han consultado el traslado contenido en ADM. Secc. Villafranca, Leg. 1, Doc. 2 (Traslado del siglo XVIII), en vez del documento inserto en ARCHV, Pergaminos, Carp. 17, doc. 9 (en traslado inserto en 30-IV-1350): así Carmelo Luis López identifica los servicios señalados como «menudería e andaduría» "Otros señoríos de los sectores...", op. cit. pg. 266; al igual que Franco Silva «Señoríos y Ordenanzas en tierra de Ávila...» Op. cit. pg. 17; por su parte Tellería Orbelzu, a pesar de haber trabajado dicho pergamino, nos habla de «montería e andaduría», «El señorío de Villafranca de la Sierra en Ávila...», op. cit. pp. 227-232.
} 
fijada con claridad la jurisdicción ejercida por el señor, tanto sobre el territorio como sobre los hombres, es decir, se establece la fiscalidad territorial y jurisdiccional denominando los pechos a contribuir directamente al señor, el cual determina una serie de exenciones a los futuros pobladores del señorío y a todo aquél que acudiera a la llamada colonizadora con el fin de obtener cada uno de los efectos jurídicos que se ofertaban. Lo que significó un instrumento eficaz en la repoblación de la zona, pues la necesidad imperante era consecuencia de la crisis demográfica y económica que en general sufrieron los territorios de la Extremadura castellana tras la conquista de los reinos musulmanes, cuestión que analizaremos más adelante en el apartado correspondiente, pues presenta ciertos interrogantes.

En otro término, nos encontramos con la administración de justicia «Et yo Esteuan Domingo de Áuila, alcallde del rey, dógela a poblar, por mi alma deste fuero ...» ${ }^{37}$. El mismo hecho de otorgar «fuero» queda comprendido en el marco privilegiado jurisdiccional, pues tal jurisdicción hace competente al señor en virtud de este privilegio para entender en todas causas civiles y criminales en que el demandado o inculpado sea natural o morador en el señorío

«Et otro, que si algunt omne morador en Villafranca algunt danno fiziere, quier por muerte, quier por ferida, quier por desonrra, quier por furto, quier por fuerça, quier por qualquier cosa que acaesca entre ellos, que [non] pechen pariente por pariente. Et otro, que si por muerte o fuerça o furto o ferida o por otra cosa qualquier que acaesca entre sí, et delos pobladores e moradores en Villafranca, tanbién los que agora son e los que serán e los que serán (sic) que se judgen por sus alcalldes de Villafranca» ${ }^{38}$.

Se trata de la atribución de una inmunidad que comprende la donación de un derecho real susceptible de enajenación, la justicia ordinaria, y más teniendo el rey la competencia exclusiva en materia criminal, la cual constituye su donación, y la legitimidad sobre la concesión de señorío jurisdiccional. En otro orden, se remarca el ejercicio de la alta y baja jurisdicción civil y criminal, el mero e mixto imperio: por un lado, la potestad que facultaba al señor a entender en causas de delitos graves, castigados con penas de muerte, mutilación, destierro o de otra índole, mediante el ejercicio de la alta jurisdicción o jurisdicción criminal o mero imperio $^{39}$; por otro, la potestad del señor para entender en las causas civiles, en su fallo y conocimiento hasta una determinada cuantía -300 maravedís según las Partidas - y la de imponer penas menores en lo criminal, generalmente pecuniarias, mediante el ejercicio de la baja jurisdicción o mixto imperio ${ }^{40}$. Ambas, alta

${ }^{37}$ ARCHV, Pergaminos, Carp. 17, doc. 9 (25-VIII-1256, en traslado inserto en 30-IV-1350); ADM. Secc. Villafranca, Leg. 1, Doc. 2 (Traslado del siglo XVI y XVIII).

${ }_{38}$ ARCHV, Pergaminos, Carp. 17, doc. 9 (en traslado inserto en 30-IV-1350); ADM. Secc. Villafranca, Leg. 1, Doc. 2 (en traslado del siglo XVI y XVIII);

${ }^{39}$ Partidas, IV, tít. 25, ley 2.

40 Partidas, III, tít. 4, ley 28. 
y baja jurisdicción, quedan configuradas en el fuero otorgado por Esteban Domingo al disponer los delitos en los que entiende y puede administrar justicia, designando los jueces ordinarios competentes en su territorio, los alcaldes ${ }^{41}$, a los cuales ordena que juzguen en los casos señalados, para determinar seguidamente una serie de garantías y prerrogativas judiciales como la facultad del inculpado de acudir en segunda instancia, en caso de agravio por la sentencia dada, al propio señor de Villafranca, reservándose éste la resolución de la apelación:

«Et si alguno se agrauiare del juyzio delos alcalldes, el que reçeviere el juyzio delos alcalldes fínquese en paz; et el que se agrauiare del juyzio delos alcalldes, denle escripto los alcalldes del juyzio que le dan, et véngase sy quisiere para mí, et para quien fincare señor desta puebla sobredicha. Et si yo, Esteuan Domingo o el otro que viniere en mío lugar por señor de Villafranca, entendiere que judgaron derecho, mandarle omnes que cunplan su juyzio así conmo le an judgado. Et si entendiéremos que alguna cosa le an de mejorar enel juyzio, enbiaremos mandar a los alcalldes de cónmo gelo mejoren" ${ }^{42}$.

A consecuencia de ello se erige con potestad para mandar las ejecuciones de las sentencias, tanto si son firmes como si tiene que resarcir a la parte agraviada. No era normal que la jurisdicción señorial ejerciera la alta jurisdicción civil y criminal, pues la justicia real se erigió como competente en el conocimiento de determinados delitos, los «Casos de Corte», que por su especial gravedad quedaban reservados al conocimiento y fallo del Tribunal de Corte instituido por el Ordenamiento de Zamora de 1274. No obstante, a veces estuvieron investidos de plenitud de jurisdicción por designación regia, lo que fue calificado por los juristas bajomedievales como mero e mixto imperio determinando los círculos de competencia jurisdiccional como se señaló más arriba.

En otro orden, respecto a las cuestiones sobre servicios y prestaciones militares, delimitadas en los términos de «hueste y fonsadera» caben ciertas reflexiones. La obligación de servicio militar venía configurada como un deber público al que estaban obligados los naturales del reino en edad y condiciones de combatir, a consecuencia de las campañas de reconquista y la defensa frente a las expediciones militares musulmanas. Los súbditos, sin diferencia de grupo social, quedaban sujetos al deber impuesto por los poderes públicos de prestar diversos servicios de armas en beneficio del reino y la comunidad. En los señoríos, era el propio señor el encargado de la exigencia de las prestaciones militares sobre los hombres sometidos a su potestad señorial en dos cuestiones: primeramente, para incorporarse con sus huestes al ejército del rey, deber del señor a consecuencia

${ }^{41}$ La jurisdicción señorial podía ser ejercida por el señor en su señorío personalmente o bien, lo que era más frecuente, que delegase su función judicial en oficiales señoriales que nombraba el propio señor, los jueces ordinarios o alcaldes. Sobre las sentencias de estos jueces ordinarios se podía apelar ante el señor, incluso de éste al rey, pues los señores nunca tuvieron una total exención de la justicia real. VALDEAVELLANO, Luis G. de., Curso de Historia de las Instituciones..., Op. cit. pg. 580-581.

42 ARCHV, Pergaminos, Carp. 17, doc. 9 (25-VIII-1256, en traslado inserto en 30-IV-1350); ADM. Secc. Villafranca, Leg. 1, Doc. 2 (en traslado del siglo XVI y XVIII). 
de la dependencia de las relaciones de vasallaje que le unían con el mismo y de las concesiones de estipendios o soldadas o de tierras en beneficio anejas a tales vínculos vasalláticos, indicando el marcado carácter feudal de los servicios militares; y en segundo lugar, al servicio del propio señor en sus propias expediciones militares. Prestaciones obligatorias en diferentes formas, según el avanzar de los tiempos. Convocada la hueste o el reclutamiento del ejército por el señor en su señorío, se unía al fonsado del rey, en el cual se integraban a su vez las milicias concejiles. Así, la hueste del señorío se incorporaba al ejército real al mando de su señor, seguido de sus propias mesnadas de vasallos y de las gentes de sus dominios, obligación que raramente eximió el rey a los habitantes de los señoríos, no concediendo el rey el privilegio de inmunidad del deber de acudir a su fonsado ${ }^{43}$. Cuestión que, en el caso que nos ocupa, claramente está eximida, puesto que el señor, Esteban Domingo, concede tal privilegio, excusando del deber de «hueste» a sus vasallos. La razón del hecho podemos encontrarla en el alejamiento de la frontera con el enemigo musulmán tras la conquista del Valle del Guadalquivir, pudiendo el rey otorgar este privilegio o inmunidad para que el señor pueda centrarse en la repoblación del lugar. Tal concesión, implica nuevamente la cesión de derechos privativos del rey, caracterizando o revistiendo el señorío de plena jurisdicción. No obstante, el señor se reserva una cláusula en caso de necesidad imperante, no concediendo la exención plena a los habitantes de su señorío del deber de prestaciones militares ${ }^{44}$ :

«Et otrosí que sean escusados de hueste e de fonsadera; fueras ende, sy fuere menester, que vayan [conmigo o] conel que fincare sennor de Villafranca ...» ${ }^{45}$.

Como se ha expuesto en el análisis de los documentos señalados, la cesión de derechos jurisdiccionales es total, por lo que se puede concluir que el señorío otorgado lleva aparejada la calificación de señorío jurisdiccional pleno y no únicamente señorío territorial o solariego. Antes de entrar en la potestad del señor para conformar mayorazgo, de lo que hablaremos posteriormente, cabe señalar una cláusula ya señalada con anterioridad en la cesión del señorío por parte del monarca y que se relaciona con la fiscalidad, reservándose el cobro de la moneda forera, sobre la cual, en la Carta Puebla otorgada por Esteban Domingo queda reflejada por «... saluo ende que den la moneda al rey, así conmo la daríen los

43 VALDEAVELLANO, Luis G. de., Curso de Historia de las Instituciones..., Op. cit. pp. 613-628.

$44 \mathrm{El}$ incumplimiento del deber de acudir a la obligación de servicios militares, se castigó inicialmente con una multa o el pago de una suma pecuniaria llamada «fossataria», pero con el tiempo la obligación de acudir a la convocatoria del ejército real pudo redimirse con el pago de una suma en metálico dando origen a un tributo ordinario, constituyéndose como uno de los derechos privativos del rey o «regalías», el caso de la «fonsadera», VALDEAVELLANO, Luis G. de., Curso de Historia de las Instituciones... Op. cit. pg. 603. Derecho que el señor posee por concesión regia, lo cual le permite mantenerlo en su reserva 0 , como en este caso, poder eximir a sus vasallos del mismo, al objeto de atraer población en su territorio.

45 ARCHV, Pergaminos, Carp. 17, doc. 9 (25-VIII-1256, en traslado inserto en 30-IV-1350); ADM. Secc. Villafranca, Leg. 1, Doc. 2 (Traslado del siglo XVI y XVIII). 
vezinos de Áuila» ${ }^{46}$. Mención a la que el señor hace referencia obligado por la única excepción que marca el rey sobre la merced dada. Ya se han expuesto ciertas aclaraciones sobre la percepción de la moneda forera más arriba por lo que sobra insistir en la misma, cabe únicamente señalar el interés que muestra Esteban Domingo, ocupado en la repoblación de su territorio, para que la vida económica del señorío de nueva creación no se vea perjudicada por la «quiebra de la moneda", justificándose en que el concejo abulense también se encuentra sujeto al pago de la misma al rey.

Moneda, justicia, fonsadera, derechos que los reyes se reservaban en los señoríos según la costumbre castellano-leonesa, tal como viene recogido en el Fuero Viejo de Castilla ${ }^{47}$. Regalías de carácter jurídico-público, atribuciones privativas del rey en el marco de los poderes e inmunidades señoriales, derechos esenciales de la potestad regia que quedan por designación del propio monarca en manos privadas como se ha mostrado más arriba. En suma, suponen una serie de privilegios enmarcados en la concesión jurisdiccional otorgada. Hecho que queda señalado posteriormente por Fernando IV, mediante confirmación dada en Medina del Campo el 26 de junio de 1302, a su descendiente Esteban Domingo, IV señor de Villafranca, y a su pedimento, para guardar y defender el derecho de sus vasallos, a lo que el rey accede ${ }^{48}$ :

«Por fazer bien e merçed a Esteuan Domingo de Ávila, mío alcallde e mío vasallo, por muchos seruiçios que fizo al rey don Sancho, mío padre que Dios perdone, e a mí, et porque me pidió por merçed que yo que viese los recabdos que él teníe de Villafranca porque fuese guardado e defendido meior el su derecho e de sus vasallos, yo tóuelo por bien».

Seguidamente, Fernando IV confirma los pechos, derechos, justicia, moneda forera y otros derechos concedidos por sus antecesores, tras analizar el ordenamiento que hizo el I señor de Villafranca y los privilegios que poseía, demostrándose el alto grado de jurisdicción señorial concedido por Alfonso $\mathrm{X}$ al abuelo del beneficiario:

«Et vi el ordenamiento que don Esteuan Domingo, su auuelo, fizo de la poblaçión de Villafranca, e las cartas e los preuilegios que este Esteuan Domingo tiene del rey don Alfonso, mío auuelo, e del rey don Sancho, mío padre, e mías. Et fallé que non ouieron nin deuíen auer los reyes dichos onde yo uengo nin yo, pechos ningunos, nin derechos, nin justiçia, nin moneda forera, nin otra cosa ninguna en Villafranca».

${ }^{46}$ ARCHV, Pergaminos, Carp. 17, doc. 9 (25-VIII-1256, en traslado inserto en 30-IV-1350); ADM. Secc. Villafranca, Leg. 1, Doc. 2 (Traslado del siglo XVI y XVIII).

47 «Estas cuatro cosas son naturales al señorío del rey, que non las deve dar a ningund ome, nin las partes de sí, ca pertenesçen a él por razón de señorío natural, justiçia, moneda, fonsadera e suos yantares», Fuero Viejo, I, 1, 1.

${ }^{48}$ ADM. Secc. Villafranca, Leg. 1, Doc. 4; ADM. Secc. Villafranca, Leg. 1, Doc. 2. (Traslado del siglo XVIII). 
El hecho confirma la realidad de la tesis que estamos defendiendo, la concesión inicial de señorío jurisdiccional pleno, hallando que el rey no tiene la potestad sobre pechos, derechos, justicia ni moneda, ni otra cosa ninguna, es decir, el señor iniciador de la repoblación del señorío de Villafranca gozó de plenos poderes en el territorio, tanto solariegos como jurisdiccionales, o dicho de otra manera, mantenía la potestad plena sobre la fiscalidad, la alta y baja justicia y el mero e mixto imperio sobre el territorio y los hombres, inmunidades y jurisdicción sobre sus vasallos en su territorio, derechos o regalías que hasta entonces habían pertenecido a la jurisdicción real. Cabe hacer un inciso sobre la justicia, pues el documento real deja claro que la misma no la ostentaba, y lo menciona de forma genérica, por lo que podemos deducir que el beneficiario del señorío tenía plena potestad jurídica en su territorio, es decir, detentaba la plena jurisdicción sobre las causas criminales y civiles, característica principal que define un señorío jurisdiccional. Y la única excepción inicialmente impuesta por el rey, Alfonso X, al otorgar el señorío, el pago de la «moneda», queda cedida por Fernando IV al descendiente del beneficiario inicial:

«Et si moneda yo ý auía o deuía auer, quítola, et dola al dicho Esteuan Domingo para sienpre jamás.»

Lo que presupone que, si el propio rey ignoraba si tal derecho le pertenecía, podemos afirmar que el señor de Villafranca nunca lo pagó, pues el monarca tendría conocimiento documental del mismo. En el párrafo anterior, al revisar los privilegios que detentaba el señor de Villafranca, el rey manifiesta no haber hallado la pertenencia al mismo de la moneda forera, para afirmar después que si en algún caso la tuviere, la cede al señor actual de Villafranca, por lo tanto la duda es obvia. La razón de ésta última concesión podemos encontrarla con toda posibilidad como consecuencia de la inestabilidad de la zona conformada en un territorio escasamente poblado, un valle perdido entre montañas, lo que imposibilitaba o al menos dificultaba el cobro del impuesto, justificando el dicho otorgamiento ${ }^{49}$.

Al final de dicho documento el rey, Fernando IV, expone una serie de cláusulas finales imponiendo sanciones pecuniarias contra aquél que no guarde la confirmación o vaya contra ella en alguna manera:

"Onde mando e defiendo firmemiente, que ninguno non sea osado de demandar ý ninguna cosa, nin de peyndrar por ello, nin de yr al dicho Esteuan Domingo contra esta merçed quele yo fago, para gela quebrantar, nin para gela menguar en ningund tienpo por ninguna manera, si non qualquier quelo fiziese $o$

49 Monsalvo Antón ve en la época al interpretar la Crónica de Ávila graves tensiones sociales motivadas por la hegemonía privilegiada de los caballeros serranos frente a ruanos en la ciudad de Ávila, yendo éstos a poblar Ciudad Rodrigo originando el enfrentamiento ya comentado más arriba por el robo de ganado. Monsalvo Antón, J. Ma.., «El realengo y sus estructuras de poder», en Historia de Ávila, III, Edad Media. Coord. SER QUIJANO, G. del. Institución "Gran Duque de Alba», Caja de Ahorros de Ávila, 2006, pp. 106-108. 
le fuese contra ello o contra alguna cosa dello o qualesquier, pecharme ý en (en) pena diez mill marauedís de la moneda que fazen diez dineros el marauedí, et al dicho Esteuan Domingo o a quien su boz touiese, todo el danno e el menoscabo que por ende reçebiese, doblado».

Por último, y sin ánimo de ser exhaustivos, basten unas breves consideraciones sobre los traslados de los privilegios referidos en la introducción, otorgados por el infante don Pedro, tío de Alfonso XI, y la reina María de Molina, viuda del rey Sancho IV y madre del infante don Pedro, ambos como tutores del rey Alfonso XI, así como el otorgado por éste, confirmando la potestad jurisdiccional que reviste el señorío de Villafranca, facultad sobre la que venimos insistiendo. Los tres privilegios referidos, otorgados en septiembre de 1313, el día 19 el primero y el 21 los dos siguientes, se refieren a una confirmación que hacen a Blasco Muñoz, V señor de Villafranca, hijo de Esteban Domingo, III señor de Villafranca, por una serie de servicios prestados al infante y a su madre, de unas casas con su torre en la calle de los Caballeros de Ávila, además del señorío de Villafranca, los cuales habían sido de su padre y abuelo y le habían sido tomados por otros parientes aprovechando su minoría de edad ${ }^{50}$. La razón de traer a colación dichos documentos, a pesar de lo avanzado de la fecha de su concesión, puesto que este Blasco Muñoz es el nieto de Esteban Domingo, el fundador del señorío y mayorazgo de Villafranca, responde a las referencias sobre jurisdicción señorial que contienen:

«E porque fallamos e tenemos que deuedes auer con derecho Villafranca, que es en Val de Corneia, e las casas de la torre que son en Áuila en la Rúa de los Caualleros, la qual Villafranca e las dichas casas fue todo de Esteuan Domingo, uuestro auuelo, e de Esteuan Domingo vuestro padre, pongo convusco de uos apoderar e entregar las dichas casas e la dicha Villafranca con todos los vasallos e pechos e derechos e con todas sus pertenençias, que las ayades daquí adelante para sienpre jamás, vos e vuestros herederos o aquél o aquéllos a quien lo vos ordenardes o mandáredes quelo aya».

Esta confirmación otorgada por el infante don Pedro es similar a las otras dos mencionadas, y determina en semejante forma la concesión de vasallos, pechos y derechos, además de pertenencias, por lo que no vamos a insistir en dichos términos y sobre su contenido o significado jurisdiccional, pues considero que la razón del presente trabajo ha quedado suficientemente aclarada, y el insistir en ello significaría un trabajo reiterativo de lo más arriba expuesto. Baste mencionar lo dicho sobre los documentos referidos.

50 La concesión del infante don Pedro en ADM. Secc. Villafranca, Leg. 1, Doc. 5 y ADM. Secc. Villafranca, Leg. 1, Doc. 2 (Traslado del siglo XVIII); la de doña María de Molina en ADM. Secc. Villafranca, Leg. 1, Doc.5, ADM. Secc. Villafranca, Leg. 1, Doc.5 (Traslado de fecha 15 de marzo de 1479), y ADM. Secc. Villafranca, Leg. 1, Doc. 2. (Traslado del siglo XVIII); y el privilegio de Alfonso XI en ADM. Secc. Villafranca, Leg. 1, Doc. 18, ADM. Secc. Villafranca, Leg. 1, Doc. 2. (Traslado del siglo XVIII), ADM. Secc. Villafranca, Leg. 1, Doc. 8. (Copia impresa del siglo XVIII sobre traslado inserto en fecha 1389 , marzo, 19), y ARCHV. 1.1. Pergaminos, Carpeta, 17, 10. (Traslado inserto en fecha 1389, marzo, 19). 


\section{HACIA LA CREACIÓN DEL MAYORAZGO O LA CONSOLIDACIÓN DE LAS RENTAS}

Respecto y volviendo al documento anterior donde Esteban Domingo otorga fuero en Villafranca, nos queda analizar la formación de mayorazgo a través de la imposición sucesoria por el dicho Esteban Domingo, I señor de Villafranca ${ }^{51}$.

«Et otrosý, yo Esteuan Domingo de Áuila, alcallde del rey, ordeno e do el señorío de Villafranca con consentimiento de mi muger donna Garoça ${ }^{52}$, e de mi fiio [Blasco] Munnoz, e de mi fiio Yuánnez Esteuan, e de mi yerno Sancho Ximeno, e de mi fiia Amunna Esteuan, e de mi fiia Domenga Gómez, e de mis nietos Yennego Ximénez e Donoro e Munnita Esteuan, enesta manera:

Que si yo finare ante que Blasco Munnoz, mío fiio, que aya él a Villafranca con todos los derechos que yo ý he o deuo auer; et si [Blasco Munnoz] non dexare fiio varón, quelo aya Yuánnez Esteuan; et si Yuánnez Esteuan finare ante que Sancho Esteuan, quelo aya Sancho Esteuan; et después que finare Sancho Esteuan, quelo aya el mi nieto mayor que fincare que sea varón; quelo aya todo libre e quito con todos sus derechos que sobredichos son».

Claramente establece una forma de propiedad vinculada para asegurar el aprovechamiento de las rentas al titular del señorío, prefijando el orden de sucesión dispuesto de manera formal en la primogenitura. Vinculación sobre la propiedad de la que el titular no puede disponer, pues como se ha dicho, el aprovechamiento solamente se sitúa sobre las rentas. Tal disposición nos lleva a determinar la existencia de dominio territorial, pues al establecer mayorazgo únicamente queda prefijado el beneficio de las rentas de un determinado patrimonio sin poder disponer del valor constituido por el mismo. No obstante, la confluencia de la vinculación de la propiedad y la sustitución sucesoria no suponen por sí la instaura-

\footnotetext{
51 ARCHV, Pergaminos, Carp. 17, doc. 9 (25-VIII-1256, en traslado inserto en 30-IV-1350). ADM. Secc. Villafranca, Leg. 1, Doc. 2 (Traslado del siglo XVI, y otro del siglo XVIII).

52 Carmelo Luis López afirma que en el traslado, se dispone como doña Gracia, a pesar de identificar a la misma como doña Garoça en el testamento, «Otros señoríos de los sectores...», op. cit. pg. 266. No obstante, en la carta puebla otorgada por Esteban Domingo se la identifica como doña Garoça, ADM. Secc. Villafranca, Leg. 1, Doc. 2 (Traslado del siglo XVI); lo mismo que en el testamento AHN. Secc. Clero. Pergaminos. Carp. 20, no 11; al igual que en ARCHV, Pergaminos, Carp. 17, doc. 9 (Traslado inserto en fecha 30-IV-1350); vid. TELLERIA ORBELZU, A. M르. «El señorío de Villafranca de la Sierra en Ávila...», op. cit. pp. 230-232. A pesar de que en todos los documentos reseñados queda identificada como doña Garoça, existen a su vez otros donde se refiere como doña Gracia: Real Academia de la Historia, en adelante, RAH., Col. Salazar y Castro, D-30, fol. 154v donde se escribe «Esteuan Domingo Dáuila, alcalde del rey, fundador y señor de Villafranca, 1216, dejola a los hijos que tubo en doña Graçia, su muger»; además se explica al inicio de dicho documento que «Pellicer sacó este árbol de la executoria», se refiere al ya citado ARCHV, Pergaminos, Carp. 17, doc. 10, conocido como el «Pleito de Villafranca»; o en otro caso al folio siguiente RAH., Col. Salazar y Castro, D-30, fol. 155r donde refiere «Doña Gracia casó con Esteuan Domingo su primo hermano, I señor de Villafranca». Sobre el traslado al que posiblemente se refiere dicho autor, quizás sea ADM. Secc. Villafranca, Leg. 1, Doc. 2 (Traslado del siglo XVIII); por su parte, Franco Silva, A. también nos habla de «doña Gracia» en «Señoríos y Ordenanzas en tierra de Ávila...", op. cit. pg. 17, lo que posiblemente indique que su fuente sea la misma que la que referimos para Carmelo Luis López.
} 
ción de la institución de mayorazgo ${ }^{53}$, pero sin analizar las distintas teorías sobre su aparición, para el objeto de este trabajo podemos determinar la existencia de la institución de mayorazgo al entender que en dicho documento se hallan los elementos constitutivos del mismo. Es verdad que solamente se impone en el documento el elemento referido a la sustitución sucesoria, es decir, se ordena la sucesión por derecho de primogenitura y por línea de varón, pero tal derecho queda vinculado al señorío «... ordeno e do el señorío de Villafranca ...»; es verdad que no se habla implícitamente de tal formación de mayorazgo, no refiriendo la unidad de tierras y derechos establecidos en el territorio, sin embargo, podemos afirmar que quedan establecidos a lo largo de la totalidad del documento analizado a que nos referimos, a la cita que acabamos de señalar, y a «... con todos los derechos que yo ý he o deuo auer ...", concretando tierras y derechos en la donación del señorío, lo que supone otro grado de jurisdicción, pues se entiende que al establecer la sucesión confirma en la misma todos los derechos inherentes al señorío, tanto territoriales como jurisdiccionales; tampoco se establece la prohibición de enajenamiento alguno sobre el mayorazgo, no obstante, el final del documento deja entrever la misma, prohibiendo a sus sucesores hacer cosa alguna en contra del fuero otorgado:

«Et otro que sy yo, Esteuan Domingo, les otorgo a todos estos pobladores sobredichos de Villafranca, por mí e por todos mis herederos asý conmo sobredicho es, de mantenerlos a este fuero; et sy sacarlos quesiéremos en alguna cosa, que nos non vala» 54 .

Para, por último y al tiempo, terminar confirmando todo lo dicho tras establecer el orden sucesorio en el señorío, vinculando propiedad y derechos al primogénito, o mejor dicho, formando mayorazgo y estableciendo la inamovilidad del fuero otorgado. Facultad que de nuevo nos introduce en las prerrogativas jurisdiccionales que mantenía Esteban Domingo, tras la concesión real, en el señorío de nueva creación; facultad de ordenar a sus sucesores establecidos por mayorazgo la necesidad y obligación de guardar el fuero instituido por él mismo.

Seguidamente, otro documento de fecha 25 de mayo de 1260, estando al frente de la herencia de su padre Esteban Domingo, Blasco Muñoz, II señor de Villa-

${ }^{53}$ CLAVERO, B., «Proceso constitutivo del mayorazgo castellano», en Mayorazgo. Propiedad feudal en Castilla (1369-1836). Siglo XXI de España, 1974, pp. 21-50- Este autor dispone que únicamente un grado especial de vinculación determinará la aparición de propiedad vinculada haciendo posible la sustitución sucesoria consiguiente a la vinculación, el mayorazgo, el cual contiene una serie de elementos jurídicos que caracterizan el mayorazgo castellano: la extensión de la vinculación de la propiedad a supuestos que no dependen de la facultad de su titular o que no implican verdadera enajenación, pues al imponer la propiedad vinculada quedan suspendidos los derechos enfrentados a la vinculación en el momento de cada sustitución, legítimas y el derecho correspondiente a los colonos en las tierras vinculadas. Por otro lado, dicho autor sitúa el momento de formación de esta institución en el siglo XIV y las concesiones Trastámaras, quedando constituido en el siglo XV.

54 ARCHV, Pergaminos, Carp. 17, doc. 9 (25-VIII-1256, en traslado inserto en 30-IV-1350). ADM. Secc. Villafranca, Leg. 1, Doc. 2 (Traslado del siglo XVI y otro del siglo XVIII). 
franca, confirma el mayorazgo familiar y la carta puebla otorgada por su padre, obligado por las cláusulas que impuso en la conformación del fuero otorgado ${ }^{55}$.

«Et yo, Blasco Munnoz, fiio de Esteuan Domingo el sobredicho, que finqué en Villafranca en lugar de don Esteuan Domingo, mi padre, vy este preuillejo que sobre dicho es, que do don Esteuan Domingo, mi padre, de Áuila, alcallde del rey, con consentimiento e otorgamiento de su muger donna Garoça, e de mí, Blasco Munnoz, e de su fiio Yuánnez Esteuan, e de su fiio Sancho Esteuan, e de su yerno Sancho Ximeno, e de su fiia Amunna Esteuan, e de su fiia Domenga Gómez, e de sus nietos Yennego Ximeno e Donoro e Monnita Esteuan.

Et yo, Blasco Munnoz, entendiendo que todo esto que do don Esteuan Domingo de Áuila, alcallde del rey, que se contiene de suso eneste preuillejio, entendiendo que es a seruiçio de Dios et a seruiçio del mucho onrrado e muy noble rey don Alfonso, a quien dé Dios vida e salud, amén, et a saluamiento del alma de don Esteuan, mío padre, et yo, Blasco Munnoz, confírmolo e otórgolo».

La misma conformación de mayorazgo requiere, por otro lado, la confirmación de la concesión o permisividad del propio rey, sin embargo, no contamos con tal concesión, pero podemos enmarcarla dentro de la propia conformación, pues Esteban Domingo se identifica otra vez como alcalde del rey, lo que pudiera suponer la propia permisividad real, no actuando el otorgante a espaldas del monarca, o en otro caso, inicia la ordenación de mayorazgo a través de la potestad concedida en la concesión del señorío «... pora façer dello todo lo que quisiere ...»56, arrogándose la facultad real donada que implica la potestad para formar mayorazgo. En otro orden, la constitución de mayorazgo es propia de la propiedad señorial o propiedad territorial feudal, incluso sin mediar fundación ${ }^{57}$; así pues, la concesión real de villa o título señorial, y aquí observamos ambas, lleva cualquiera de ellas implícita la fundación de dicho mayorazgo sin restricción alguna. Por tanto, podemos concluir que al establecerse la sucesión en el señorío por primogenitura y línea de varón, confluye en el mayorazgo la jurisdicción dependiente de dicho señorío, por lo que se puede definir como un señorío hereditario, indivisible e inalienable, primitiva forma de la institución de mayorazgo; y por tanto confirma, a grandes rasgos, las características o elementos que lo constituyen mantenidos por Bartolomé Clavero ${ }^{58}$.

Por último y para terminar este apartado, cabe reseñar como prueba final el ya mencionado «Pleito de Villafranca», donde las referencias al citado mayorazgo son constantes por unas y otras partes del conflicto, aludiendo a su formación por Este-

55 ARCHV, Pergaminos, Carp. 17, doc. 9 (6-V-1260, en traslado inserto en 30-IV-1350), y ADM. Secc. Villafranca, Leg. 1, Doc. 2. (Traslado del siglo XVIII). Como se dijo más arriba, dicho documento confirma que la muerte de Esteban Domingo ocurrió antes de la citada fecha de 25 de mayo de 1260.

${ }^{56}$ ADM. Secc. Villafranca, Leg. 1, doc. 1, y ADM. Secc. Villafranca, Leg. 1, Doc. 2. (Traslado del siglo XVIII).

57 CLAVERO, B., Mayorazgo..., Op. cit. pg. 49.

58 CLAVERO, B., Mayorazgo... Para determinar los elementos que configuran la constitución de mayorazgo se apoya en la Leyes de Toro de 1505, y sobre ellas se retrotrae a épocas anteriores buscando tales caracteres. 
ban Domingo cuando pobló Villafranca. No vamos a reproducir el citado documento en el anexo documental por su gran extensión como ya dijimos en nota, pero si reflejaremos una parte del mismo por su importancia sobre el tema que tratamos, exactamente la parte que incluye la sentencia dada por los oidores de la Audiencia por considerarlo de suma importancia. Se trata de una ejecutoria sobre un pleito dada en Alcalá de Henares el 19 de marzo de 1389, entre Teresa González y su hijo Alfonso Ortiz, contra Juan Sánchez Redondo, vecino de Arévalo, sobre el lugar de Villafranca y unas casas en Ávila con su torre, por merced que hizo el rey don Enrique en 1366 por culpa que resultó contra Gonzalo González, hermano de doña Teresa, en Montiel. Y ésta mantenía que le pertenecía por la fundación que en 8 de enero de 1328 hizo su dicho hermano, a cuyo pleito se opone Sancho Sánchez, hijo de Nuño Mateos de Ávila, y Pedro González, hijo de Esteban Domingo de Ávila y Gimena Blázquez. Por esta ejecutoria simple se declaró que la fundación que hizo Esteban Domingo, era mayorazgo con las casas y torres de Ávila, y todo pertenecía a dicho Pedro González como heredero directo y pariente mayor, descendiente por línea masculina del linaje de Esteban Domingo, el cual ordenara dicho mayorazgo:

«Et visto e esaminados los recabdos que por las dichas partes enel dicho pleito fueron presentados, e todo lo que cada una de las dichas partes dixieron e razonaron enel dicho pleito; e auido su acuerdo sobrello, fallaron que así por las escripturas [e recabdos que fueron presentados enel dicho] pleito por la parte del dicho Alfonso Ortiz e de la dicha Teresa Gonçález, su madre, conmo por la parte del dicho Pedro Gonçález, que se prouara asaz quánto conplía de derecho que el dicho lugar de Villafranca con sus derechos e con sus términos e pertenençias, et las dichas casas de Áuila con su [torre, sobre que era la contienda del dicho pleito, que] era mayoradgo e que fuera condiçionado por mayoradgo por el dicho Esteuan Domingo, fiio del dicho Yuánnez Esteuan, e nieto del dicho don Esteuan Domingo, que paresçíe que poblara primeramiente la dicha Villafranca, e que ordenara el dicho mayoradgo primeramiente dello, e que fuera auido después [por mayoradgo por los parientes] desçendientes del linaje del dicho don Esteuan Domingo fasta el tienpo del dicho Gonçalo Gonçález que agora a postremas moriera» 59 .

Claramente se confirma la institución de mayorazgo ordenada por Esteban Domingo, reflejada en el fallo al señalar «... que era mayoradgo e que fuera condiçionado por mayoradgo ...", así como por las numerosas declaraciones de las partes que presentan documentos de prueba en las que se menciona y corrobora lo ya apuntado:

«... sobre el dicho lugar de Villafranca que es en Valdecorneja, e sobre las dichas casas que fueron de don Esteuan Domingo el Viejo de Áuila. El qual dicho lugar de Villafranca e casas fincaran por mayoradgo fecho e ordenado por el dicho Esteuan Domingo, e después por los otros sus desçendientes que dél heredaran el dicho mayoradgo para el nieto mayor que desçendiese de aquel linage .... ${ }^{60}$.

${ }^{59}$ ARCHV, Pergaminos, Carp. 17, doc. 10 (Traslado inserto en fecha 1389, marzo, 19).

60 lbídem. 
Y también:

«Contra lo qual, el dicho Domingo Sánchez, en nonbre del dicho Pedro Gonçález, en respondiendo, dixo que en la manera que fuera estableçido e ordenado el dicho mayoradgo, e segund los ordenamientos e condiçiones que fueron fechos e ordenados, e estableçido por el dicho don Esteuan Domingo que estableçiera e feziera el dicho mayoradgo, e segund la postura e abenençia e trasaçión e condiçiones fechas e estableçidas e otorgadas después por los otros desçendientes de[I] linage del dicho don Esteuan Domingo...» ${ }^{61}$.

Y otras muchas que no vamos a mostrar por resultar prolijo, pero que pueden encontrarse en dicho documento. Aunque cabe señalar un testamento presentado por Domingo Sánchez:

«Otrosí, presentó una carta del rey don Alfonso, por la qual carta el dicho rey don Alfonso enbió mandar al conçeio de la çibdat de Áuila, de villa e de aldeas, e a los alcalldes, tanbién de la villa conmo de la hermandat, que ayudasen al dicho Blasco Munnoz a entregarse en las casas de la torre de la dicha çibdat de Áuila, e enel dicho lugar de Villafranca con vasallos e derechos e usos e pertenençias. Et que [mandase] al conçeio e a los omnes buenos del dicho lugar de Villafranca que reçebiesen al dicho Blasco Munnoz por su sennor. Et quele recodiesen con todos los derechos e pechos e con todas las otras cosas, segund que más conplidamiente recodieran a los que ouieran el dicho lugar.

La qual carta paresçía que fue dada en Áuila, veynte e un días [de setienbre], era de mill e trezientos e çinquenta e un annos» ${ }^{62}$.

Y los traslados de los privilegios dados por el infante don Pedro y la reina doña María de Molina, como tutores de Alfonso XI, y el dado por él mismo, como ya referenciamos con anterioridad y se consignan en la nota que precede ${ }^{63}$. En ellos se recoge por un lado, la obligación del concejo de la ciudad de Ávila y de las villas y aldeas y sus alcaldes, de reconocer por orden real a Blasco Muñoz, V señor de Villafranca ${ }^{64}$, en las casas de la dicha ciudad y en la villa de Villafranca, es decir, el reconocimiento de su mayorazgo; por otro, termina con la confirmación real de vasallos, derechos, usos y pertenencias que se contenían en el señorío, cuestión apuntada en su momento. Sin embargo, lo que más nos interesa

61 Ibídem.

62 Ibídem. Vid. ADM. Secc. Villafranca, Leg. 1, Doc. 18; ADM. Secc. Villafranca, Leg. 1, Doc. 2. (Traslado del siglo XVIII); y ADM. Secc. Villafranca, Leg. 1, Doc. 8 (Copia impresa del siglo XVIII sobre traslado inserto en fecha 1389, marzo, 19).

${ }_{63}$ A los documentos referenciados ut supra, podemos añadir ADM. Secc. Villafranca, Leg. 1, Doc.5, y ADM. Secc. Villafranca, Leg. 1, Doc.5 (Traslado de fecha 15 de marzo de 1479).

${ }^{64}$ Este Blasco Muñoz es el V señor de Villafranca, hijo de Esteban Domingo, III señor de Villafranca, y nieto de Esteban Domingo el fundador y I señor de Villafranca, y heredó el señorío de su primo hermano Esteban Domingo, IV señor de Villafranca, el cual a su vez heredó el señorío de su tío Sancho Esteban, padre de Blasco Muñoz, que después adoptó el nombre de Esteban Domingo, III señor de Villafranca. ARCHV, Pergaminos, Carp. 17, doc. 10. SNAHN, Secc. Parcent, C. 123, doc. 30. RHA, Colecc. Salazar y Castro, D-30, fol. 154v. 
en este apartado son las menciones sobre la propiedad del mayorazgo que confirman en dichos documentos:

"La qual Villafranca e las dichas casas fue todo de Esteuan Domingo, vuestro auuelo e de Esteuan Domingo, vuestro padre».

Reconociendo o motivando el porqué se devuelve el señorío y las casas de Ávila al nieto de Esteban Domingo como descendiente del fundador, cuestión que nos lleva a considerar las cláusulas de todo mayorazgo establecido, el cual en caso de pleito o litigio sobre la propiedad del mismo se debe retrotraer a la imposición del fundador para designar el heredero.

«Sepades que porque fallé que Esteuan Domingo, padre de Blasco Munnoz, de ý de Áuila, teníe e auíe a Villafranca que es en Val de Corneia, e las casas dela torre que son en Áuila en la Rúa de los Caualleros, al tienpo que murío en seruiçio del rey don Sancho, mi auuelo que Dios perdone. Et que este dicho Blasco Munnoz, fincó su fijo mayor e heredero del dicho lugar de Villafranca e de las casas e de los otros bienes que su padre dexó, et porque fincó pequeño e sin edat e algunos sus parientes tomaron e entraron los dichos bienes conmo non deuíen seyendo él pequeño conmo dicho es, e non lo podiendo demandar fasta aquí, pidiome merçed quele fiçiese entregar el dicho lugar de Villafranca con sus pertenençias e las dichas casas conmo dicho es" ${ }^{65}$.

O lo que es lo mismo, en el mayorazgo no se sucede por «derecho hereditario» sino que prima el «derecho de sangre». En el mayorazgo se es sucesor de forma estricta del fundador y no del antecesor, aunque medien siglos, siendo designado el traspaso de la posesión en el momento del acto de fundación a todos los que hayan de suceder en el mismo para que lo tenga cada uno en su momento. Cuestiones o principios consustanciales del régimen de mayorazgo, y que tendrán su afirmación en el ámbito procesal con «el juicio de tenuta» ${ }^{66}$, puesto que «en el mayorazgo todas las reglas ceden a la voluntad del fundador» 67 .

\section{LA REPOBLACIÓN DEL SEÑORIOO O «REPOBLACIÓN TARDÍA»}

Aclarada la situación jurídica del señorío comentado, y disponiendo con toda seguridad la forma contenida, es decir, la situación plenaria de señorío jurisdiccional de la zona referida, pues en otro orden, llamaría la atención que significara únicamente una concesión de señorío territorial cuando ya se aprecia en la $2^{a}$ mitad del siglo XIII un cierto predominio de elementos jurisdiccionales en tales

${ }^{65}$ ADM. Secc. Villafranca, Leg. 1, Doc. 18, y ADM. Secc. Villafranca, Leg. 1, Doc. 2. (Traslado del siglo XVIII).

66 CLAVERO, B., Mayorazgo..., Op. cit. pp. 249-254.

67 Dice la regla doce de las formuladas por Salas para el mayorazgo, invocando la Ley 40 de Toro, recogiéndola para el caso concreto del orden sucesorio; CLAVERO, B., Mayorazgo..., Op. cit. pg.222. 
donaciones, abordaremos la cuestión de la repoblación. Como ya apuntamos, no podemos olvidar, y volvemos a insistir en ello, que al constituirse la zona tratada en un territorio yermo y prácticamente despoblado, alejada del centro administrativo abulense y de difícil control, la necesaria repoblación se lleva a cabo por manos particulares previa donación real. Lo que nos sumerge en otro problema, el cual a su vez, constituye otra realidad firme del análisis de este trabajo. El objetivo es averiguar el porqué de esta concesión de jurisdicción plena y temprana de poder señorial, de jurisdicción civil y criminal e mero e mixto imperio, algo inusual para la época, puesto que tal concesión es más propia de los tiempos de Enrique II de Trastámara cuando queda normalizada tal merced, como se ha dicho. La cuestión es conocer las causas que llevaron a Alfonso X, el Sabio, a otorgar un señorío jurisdiccional en Villafranca de la Sierra o de Corneja, como era conocida en la época, territorio de carácter realengo, enajenándolo de la Tierra de Ávila.

Ya hace años don Claudio Sánchez Albornoz al estudiar las consecuencias de la colonización de las tierras del sur de la península tras la batalla de Las Navas de Tolosa, concluía que se produjo una gran corriente migratoria desde el norte, influyendo en la economía de Castilla y León, puesto que en menos de cuarenta años se duplicó el terrazgo a cultivar sin apenas incremento demográfico alguno ${ }^{68}$. Poco tiempo después, Luis G. de Valdeavellano desarrolló la hipótesis de su maestro disponiendo que, desde la primera mitad del siglo XIII, la emigración originada por las conquistas territoriales a costa de los musulmanes, crearon una crisis agrícola en Castilla y León debido a que tales tierras tuvieron que ser repobladas por gentes del norte peninsular originando gran escasez de mano de obra como consecuencia de lo apuntado por don Claudio ${ }^{69}$. Tal aseveración ha predominado hasta hoy día, siendo admitida plenamente la generación de una crisis agrícola como consecuencia de una emigración provocada por la Reconquista, amén de otras circunstancias. Por otro lado, Nicolás Cabrillana estudiando la repoblación andaluza, afirma que se produjo un trasvase ingente de población desde la meseta norte dando lugar a la aparición de despoblados en la zona del Duero debiendo quedar exhausta ${ }^{70}$. La misma conclusión contempla Iradiel al analizar el proceso de remodelación del hábitat rural de la zona del Duero, sobre el cual dispone que la ocupación del valle del Guadalquivir atrajo grandes contingentes de población procedentes de la meseta norte, produciendo despoblados en los lugares más pequeños de la zona, especialmente en el norte y en menor proporción en la cuenca sur ${ }^{71}$.

68 SÁNCHEZ ALBORNOZ, C., España, un enigma histórico, t. II. Barcelona, 1983, 8ª Reimp. pp. $123-124$

69 VALDEAVELLANO, Luis G. de., Curso de Historia de las Instituciones..., op. cit. pg. 262.

70 CABRILLANA, N., «Los despoblados en Castilla la Vieja», en Hispania, 120, 1972, pp. 21-25.

71 IRADIEL, P., MORETA, S. y SARASA, E., $H^{a}$ medieval de la España cristiana. Madrid, Ed. Cátedra, 1989, pg. 475. 
Por otro lado, Manuel González Jiménez analizando las consecuencias de la conquista del Guadalquivir, y tras citar las conclusiones de los autores anteriores, mantiene serias dudas sobre el proceso descrito, planteando la cuantificación de la migración hacia el sur y la incidencia de ésta en las tierras de origen ${ }^{72}$. Sobre ambas cuestiones, se pregunta si en verdad la migración desde la meseta, que estima en unos cien mil individuos, supuso un esfuerzo traumático para la zona ocasionando despoblados, o bien significó el descargo de la presión demográfica, la cual duda que existiera, reactivando el mercado de la tierra al abrir el acceso a la propiedad a campesinos carentes de ellas y frenando las particiones de heredades que empobrecían a los pequeños campesinos. Lo que no duda es sobre las consecuencias negativas que afectaron a una minoría de la población, en este caso, los señores, pues gran parte de los emigrados serían jóvenes y dependientes, por lo que se generó en general un descenso de las rentas señoriales, sobre todo en las rentas decimales de la Iglesia. Por otro lado, acepta la crisis económica del siglo XIII, unánimemente admitida, pero no su explicación, pues no concuerda con T. F. Ruiz que afirma que la causa de la crisis económica, social e institucional de Castilla en el siglo XIII fue la expansión por las tierras andaluzas, señalando el desplazamiento de la nobleza hacia el sur, la cual fue acompañada por campesinos libres y pequeños terratenientes a la búsqueda de nuevas condiciones económicas, aún a costa de perder su libertad, amén de atribuir otra serie de consecuencias generadas por la conquista del Guadalqui$\mathrm{vir}^{73}$. Sobre la tesis de Ruiz considera que es exagerada, puesto que sin negar la significación de las grandes propiedades que surgieron, la nobleza castellana se desinteresó tempranamente de su explotación, no pudiendo constatar en documentación alguna que tras los repartos trasladasen su residencia al sur, considerando que no puede ser esta única explicación la consecuente de la crisis. Para ello añade una serie de preguntas sobre fiscalidad real, la situación del campesinado en la época, las dificultades de villas y aldeas sobre el esfuerzo económico y demográfico que supuso la conquista y los despoblados originados, las medidas forales otorgadas para frenar la migración campesina, tanto hacia el sur como a zonas limítrofes, y por último, respecto a la degradación progresiva del campesinado castellano ${ }^{74}$. Preguntas de difícil respuesta, puesto que los estudios realizados sobre el tema aún son vagos y escasos. En respuesta al análisis de rentas y dominios señoriales en el siglo XIII, conocemos la evolución de los dominios monásticos, bastante menos sobre los dominios catedralicios, y apenas

72 GONZÁLEZ JIMÉNEZ, M., «Del Duero al Guadalquivir: repoblación, despoblación y crisis en la Castilla del siglo XIII», en Despoblación y colonización del valle del Duero, Siglos VIII-XX. IV Congreso de Estudios Medievales. Fundación Sánchez Albornoz, Ávila, 1995, pp. 209-224.

${ }_{73}$ Tal afirmación queda contenida en RUIZ, T. F., «Expansión y crisis. La repercusión de la conquista de Sevilla en la sociedad castellana, 1284-1350", en Sociedad y poder real en Castilla. Barcelona, 1981, pp. 11-69. Para negar tal afirmación se apoya en GAUTIER-DALCHÉ, J. «L'historie Castilla dans la première motié du XIV e siècle», en Anuario de Estudios Medievales, 7, 1970, pg. 239; afirmando que las conquistas andaluzas y murcianas, los trasvases de población y los reajustes económicos afectaron sin lugar a dudas al conjunto castellano.

74 GONZÁLEZ JIMÉNEZ, M., «Del Duero al Guadalquivir...», op. cit., pg. 221. 
nada sobre los dominios nobiliarios. Lo que sí es claro es la existencia de la crisis agrícola castellana, pero claramente su origen se sitúa más allá de dicho siglo: es evidente a finales del mismo ${ }^{75}$; García Sanz dispone su existencia en la primera mitad del siglo, anotándola como uno más de los componentes de una "crisis económica» ${ }^{76}$; las reformas monetarias proteccionistas de Alfonso X permiten a Sánchez Albornoz centrar el inicio de la crisis en dicho reinado, calificándolas como «economía dirigida»77; la publicación de las «posturas» de Alfonso VIII, correspondientes a unas cortes celebradas en Toledo en 1207, permiten a su editor, Hernández, F. J., opinar que dicha legislación fue utilizada en cortes posteriores por Alfonso $X^{78}$. Por lo tanto, las dificultades tenían su inicio, al menos, desde inicios del siglo XIII. No obstante, en la zona abulense, los problemas en el sistema se detectan desde finales del siglo XIII, en concreto desde 1280, cuando se vislumbran algunos síntomas de agotamiento, para producirse la crisis global del sistema al comienzo de la centuria siguiente, presentándose una recesión económica, la contracción de las fuerzas productivas y el desplome de las rentas feudales, acentuando los antagonismos y las contradicciones entre los distintos grupos, privilegiados o no ${ }^{79}$.

Sin embargo, la consecuencia importante aquí, fue la creación, a resultas de los hechos, de despoblados en las comarcas de la Meseta del Duero. El caso es que en la zona que nos ocupa, el lugar de Villafranca de la Sierra, desconocemos el grado demográfico que tenía en la época. Indudablemente como despoblado ${ }^{80}$ o al menos de escasa población ${ }^{81}$, era una zona situada en la sierra, cerca de la Sierra de Gredos, aunque a menor altitud, no muy propicia para la agricultura, pues era en general un territorio yermo, pero sí favorable para la explotación ganadera. En cualquier caso, los datos de poblamiento de que disponemos sobre la zona del Duero, tanto al norte como al sur, nos permiten afirmar sin duda alguna, que la situación se traducía en un poblamiento extraordinariamente disperso con una escasa entidad poblacional ${ }^{82}$, por lo que podemos deducir que el caso de Villafranca no tenía por qué ser diferente. En suma, suponía un territorio yermo y de escasa o ninguna población, estratégicamente situado para el paso trashumante del ganado y su explotación, alejado del centro administrativo abulense y por tanto de difícil control.

75 VALDEAVELLANO, Luis G. de., Curso de Historia de las Instituciones..., op. cit. pg. 262.

76 VAlDEAVELLANO, L. G. de, y GARCíA SANZ, A., Propiedades del cabildo segoviano, sistemas de cultivo y modos de explotación de la tierra a fines del siglo XIII. Salamanca, 1981, pp. 87-87 y 94.

77 SÁNCHEZ ALBORNOZ, C., "Alfonso el Sabio y la economía dirigida», en Ensayos sobre historia de España. Siglo XXI, Madrid, 4⿳亠丷a edic. 1989, pp. 75-82.

78 HERNÁNDEZ, F. J., «Las Cortes de Toledo de 1207», en Las Cortes de Castilla y León en la Edad Media, I. Valladolid, 221-263.

79 BARRIOS GARCÍA, A., Estructuras agrarias y de poder en Castilla..., Op. cit. pp. 10-11.

80 FRANCO SILVA, A., «Señoríos y Ordenanzas en tierra de Ávila...», op. cit. pg. 13.

81 MOZO CILLERO, C., Villafranca de la Sierra..., Op. cit. pg. 22.

82 BARRIOS GARCÍA, A. y MARTÍN EXPÓSITO, A., «Demografía medieval: Modelos de poblamiento en la Extremadura castellana a mediados del siglo XIII», en Studia Histórica, 1, no 2, 1983, pp. 113-148. 
De todas formas, la concesión del lugar de Villafranca a Esteban Domingo no fue casual ni excepcional, pues, desde mediados del siglo XIII, era habitual que la corona entregara tierras a la caballería villana de las ciudades de la Extremadura castellana para que personalmente procedieran a la «repoblación tardía» de ciertos territorios «vacíos", a fin de atraer campesinos para la explotación de esos predios. La Corona, ocupada en la repoblación andaluza, no disponía de efectivos humanos suficientes para poblar los territorios conseguidos recientemente, amén de los que ya poseía, por lo que se recurrió en la zona del interior del reino para paliar las diferencias, el caso que nos interesa, al modelo de repoblación concejil y señorial ${ }^{83}$, valga como ejemplo añadido los casos de Navamorcuende y Velada sacados a la luz por Moxó ${ }^{84}$. Por consiguiente, se trataba de un recurso habitual en la zona, probando claramente la despoblación de estos lugares.

Por su parte, Ángel Barrios realiza un sucinto estudio sobre los cambios geográficos de los asentamientos humanos en la zona del Duero, haciendo hincapié en la desaparición de núcleos de población viejos o despoblados y en la creación de nuevos asentamientos, su jerarquización y cristalización, partiendo del análisis comparativo de diversas zonas al norte de la Sierra de Gredos ${ }^{85}$. Confirma demasiados cambios habidos en un período relativamente corto, originando problemas cuando se forman estos cambios demográficos que reflejan una profunda crisis agraria, lo que podría suponer el inicio de la crisis estructural feudal, poniendo en cuestión su propia obra Estructuras agrarias y de poder en Castilla: el ejemplo de Ávila, al observar en la misma la multiplicación de las «crisis locales» en el período referido.

Tras la conversión de los territorios castellanos del sur del Duero en zona de retaguardia en las décadas centrales del siglo XIII, la situación demográfica en la zona abulense, estudiada por Ángel Barrios, mediante un documento remitido en 1250 por el cardenal Gil Torres al obispo y cabildo abulense que establece el monto de rentas correspondientes a la mesa episcopal y capitular ${ }^{86}$, queda caracterizada por un elevado número de núcleos de población en la parte norte y central de la diócesis, mientras que la ocupación era muy baja al sur de las alineaciones montañosas centrales presentando escasos núcleos poblacionales, al tiempo

${ }^{83}$ FRANCO SILVA, A., «Señoríos y Ordenanzas en tierra de Ávila...», op. cit. pg. 14.

${ }^{84}$ MOXÓ, S. de., Los señoríos de Toledo. Universidad Complutense. Publicaciones del Centro Universitario de Toledo. Toledo, 1972. A éstos se pueden añadir los señoríos de Villatoro y San Román. No parece que la ciudad de Ávila se opusiera a la enajenación de su alfoz de estos territorios; en suma, suponía el ascenso de los caballeros-villanos caracterizados como el grupo de los serranos, enriquecidos por las razzias fronterizas a los que la monarquía encargó la defensa del territorio, al tiempo que acaparaban los oficios del cabildo municipal abulense, (ver Franco Silva, A., op. cit. "Señoríos y Ordenanzas en tierra de Ávila...", pp. 16-17). Este autor, analizando la concesión señorial de Velada, ve una concesión señorial territorial, y por analogía lo aplica a la concesión de Villafranca, citando incluso la reserva por el rey del pago de la moneda forera. Como se ha explicado más arriba, pensamos que la concesión, al menos en el caso de Villafranca, es de jurisdicción plena y no solamente solariega o territorial.

${ }_{85}$ BARRIOS GARCÍA, A., «Poder y espacio social: Reajustes del poblamiento y reordenación del espacio extremadurano en los siglos XIII-XV», Despoblación y colonización del valle del Duero, Siglos VIII-XX. IV Congreso de Estudios Medievales. Fundación Sánchez Albornoz, Ávila, 1995, pp. 225-276.

${ }^{86}$ BARRIOS GARCÍA, A., Estructuras agrarias... Op. cit. pp. 12-41. 
que eran pequeños en tamaño y en población concentrada en aldeas y alejadas entre ellas, típico hábitat de los valles cerrados y de las comarcas de repoblación tardía, condicionadas por la configuración del relieve y la dedicación de sus habitantes al pastoreo trashumante. En consecuencia, la alta densidad ocupacional de los núcleos del norte contrasta con las comarcas meridionales serranas, las cuales presentan numerosos espacios sin asentamientos humanos fijos. La causa la podemos encontrar en la condición geográfica, los fuertes desniveles, los suelos rocosos y las numerosas corrientes de agua que condicionaron su economía ganadera, al tiempo que configuró la concentración de la población en lugares distantes entre sí. Características que podemos extrapolar a la zona que nos ocupa. Y por lo que respecta a la incidencia de la conquista y repoblación andaluza por Fernando III y Alfonso X, tampoco en la región abulense se percibe una emigración masiva, puesto que se hubiera generado una serie de despoblados que el citado documento no contempla. Admitida la participación de las milicias abulenses en la conquista de Baeza, Jaén y Úbeda, no se observa el desplazamiento masivo de gentes en la zona, ni siquiera tras la conquista efectiva del valle del Guadalquivir, más bien existen indicios de un incremento demográfico durante la segunda mitad de siglo, creándose en el obispado numerosos y nuevos núcleos poblacionales, obedeciendo al crecimiento vegetativo de la población ${ }^{87}$.

En otro orden atendiendo al nombramiento o concesión de las garantías jurisdiccionales al orden caballeresco en la zona de frontera de la Extremadura castellana, debemos acudir a las estructuras de poder en el sistema estamental imperante en el momento. De forma lenta pero paulatina, asistimos a un cambio en la estructura social de la Extremadura castellana respecto a las tierras del norte organizadas en señoríos. La zona que nos ocupa es tierra de caballeros, cuyo recurso económico es el ganado y el botín, organizada en concejos. Y son los descendientes de los líderes de las revueltas del siglo XII88 los que comparten, junto a los miembros de la caballería urbana, pero con preeminencia de éstos, los privilegios resultantes del monopolio del poder urbano. Resultado de la integración de estos dos grupos, se configurará la aristocracia urbana, y a partir de este proceso se encumbrarán unas pocas familias a fines del siglo XIII, en una situación de privilegio y dominio en la sociedad urbana. Claro está que desde mediados del siglo XIII el cargo de «adalid» que denota la función militar de los caballeros desaparece de la documentación, lo que implica que la oportunidad económica de la guerra ha desaparecido, provocada esencialmente por el alejamiento de la frontera. En suma, no debe extrañarnos que desde mediados del siglo XIII los cargos militares desaparezcan de las genealogías, no siendo casual

87 BARRIOS GARCÍA, A., Estructuras agrarias... Op. cit. pp. 41-53.

88 A parte de estar documentadas en Sahagún, Santiago y Lugo, por los nuevos grupos económicos como reacción contra la dominación señorial, también aparecen en algunos concejos fronterizos como la ciudad de Ávila, según noticias de la Crónica de la población de Ávila, en un intento de integrarse en el sistema y en las estructuras de poder; MíNGUEZ FERNÁNDEZ, J. Ma․, Las sociedades feudales, I, Madrid, Nerea, 1994, pp. 253-270. 
que Alfonso X en 1256 conceda a los caballeros de Ávila y Arévalo una serie de fueros. Tales concesiones regias, a las que se pueden añadir otras posteriores suponen el final de un proceso evolutivo desde una sociedad abierta a estructuras cerradas y hereditarias, suponiendo paradójicamente que los guerreros de frontera se transformen en caballeros o señores propietarios con cierta función militar, conformándose a la vez la caballería villana como expresión jurídico-política del dominio y hegemonía del grupo social privilegiado de los mismos caballe$\operatorname{ros}^{89}$. De todas formas, seguramente los privilegios de 1256 no hicieron más que regular una situación que ya se daba de facto. La documentación presenta numerosas evidencias para asegurar que los caballeros suponían un grupo privilegiado que les garantizaba el disfrute de señoríos y el control de las instituciones municipales, además de conformarse como «señores de ganado» y dueños de grandes extensiones de cultivo, en un intento de salvar su economía degradada por el alejamiento de frontera, y que supone su total exclusión del resto de la sociedad no privilegiada. Su control del concejo, cuyo origen se encuentra en el anterior control ejercido en el concejo de frontera por estos guerreros-pastores, supone el monopolio oligárquico y cerrado de la totalidad de los oficios concejiles, perpetuándose hereditariamente dentro del linaje, suponiendo en suma, que esta antigua aristocracia militar se consolide como aristocracia política ${ }^{90}$.

Este control por parte de los caballeros de las instituciones concejiles, además de reportarles prestigio, pudo redundar en la obtención de beneficio propio y del linaje, utilizando los resortes del poder concejil. Sobre este asunto podemos traer de nuevo a colación la concesión real de Alfonso $\mathrm{X}$ a Esteban Domingo, donde expresiones como «... por los muchos seruiçios que me fizo Esteuan Domingo de Áuila, mío alcalde, dol e otórgol a Villafranca con todo su término...» nos legitiman para poder afirmar el apoyo regio y la influencia del beneficiario en la institución municipal. Esteban Domingo actúa como alcalde del rey, lo que supone el control en el concejo, y aunque no contamos con la autorización o concesión concejil, como comentamos más arriba, podemos presuponer el interés del mismo en la repoblación de la zona que hasta ahora se encontraba dentro del término de su jurisdicción. Podemos realizar tal afirmación porque el expediente nos es privativo de la zona que trabajamos, ni siquiera de la propia tierra de Ávila, pues se extendió sobre todo el territorio de la Extremadura castellana, siendo la tónica general en la zona ${ }^{91}$, corroborando la frecuencia de semejantes concesio-

89 BARRIOS GARCÍA, A., Estructuras agrarias... Op. cit. pg. 140.

90 Tesis mantenida por GONZÁLEZ, J., Reinado y diplomas de Fernando III, II, Monte de Piedad y Caja de Ahorros, 1986. pg. 202; RUIZ, F. T., Sociedad y poder real en Castilla, Ariel, 1981, pp. 121-144; GAUTIER DALCHE, J., $H^{a}$ urbana de León y Castilla en la Edad Media, (Siglos IX-XIII. Siglo XXI de España, 1979. pp. 359-369; y BARRIOS GARCÍA, A., Estructuras agrarias... Op. cit. pg. 141.

91 GONZÁLEZ, J., «La Extremadura castellana al mediar el siglo XIII». Hispania. 1974, pp. 374-377. Dicho autor al revisar tales concesiones, desdice el carácter extraordinario de ciertas concesiones abulenses, opinión mantenida por SÁNCHEZ ALBORNOZ., Señoríos y ciudades. AHDE, 1929, pp. 454-462; GRASSOTTI, H., Un abulense en Beaucaire, CHE, 1967, pp. 133-153; y ¿Otra osadía abulense?, CHE, 1968, pp. 329-340. 
nes. La consecuencia de las mismas, convirtió a los beneficiarios, los caballeros, en receptores de los excedentes generados en sus señoríos, y les supuso el ascenso en la corte al mismo nivel que la nobleza tradicional. Como ejemplo podemos constatar a Blasco Ximeno, además del propio Esteban Domingo, y a otros señores miembros de la caballería urbana de Ávila, como Garci González y Sancho Blázquez ${ }^{92}$. La meta a conseguir, la búsqueda de nuevas rentas o una nueva economía sustitutoria, además del prestigio que otorgaba la posesión de la potestad jurisdiccional, supone la razón por la cual se procura la transmisión dentro del linaje con prácticas sucesorias determinadas, bien como un orden sucesorio necesario o bien como una alternativa. Lo cierto es que sea de la forma que fuere, la necesidad económica del orden caballeresco les obligó a la detracción de rentas por diferentes vías, en este caso, mediante la formación de la institución de mayorazgo, que creemos que ha quedado suficientemente clara, se aseguraban el aprovechamiento de las rentas mediante la vinculación.

El bloqueo de la guerra y el alejamiento de la frontera no supusieron la merma económica de los caballeros concejiles, pues asumieron la delimitación y defensa del nuevo marco territorial, atribuyéndose, bien desde la potestad señorial particularmente, bien desde el ejercicio de la soberanía concejil, la exclusividad de la explotación agro-ganadera en el territorio. La defensa del mismo, supone el mantenimiento de pastos para el ganado y rentas producidas por su tránsito, lo que les lleva a la disposición arbitraria de la dehesa concejil y comunales de aldea, incluido su propia posesión individual de pasos de ganado trashumante. Este aprovechamiento económico unido a la cesión de potestad jurisdiccional, supuso la creación de una nueva aristocracia local y una nueva reestructuración del territorio conformándose como un mosaico señorial en el antiguo alfoz abulense.

Esta aristocracia local se componía inicialmente en exclusiva por los llamados serranos, grupo hegemónico que controlaba los cargos concejiles abulenses. Pues bien, la concesión de privilegios por parte del monarca en $1256^{93}$, incluso las posteriores de $1264^{94}$ y $1273^{95}$, en Ávila a los caballeros villanos ha sido interpretada como un reconocimiento real de la primacía de este grupo. Por su parte, Monsalvo Antón ${ }^{96}$ saca conclusiones distintas, interpretando los mismos como un intento de creación de elites urbanas homogéneas con la intención de desvirtuar la superioridad consolidada por los repobladores privilegiados, generando una

92 BARRIOS GARCÍA, A., Estructuras agrarias... Op. cit. pg. 146. Citados respectivamente en Crónica del rey don Alfonso Décimo, B.A.E. LXVI. Madrid, 1953, pg. 20; Crónica del rey don Fernando IV, B.A.E., pg. 113; y Crónica del rey don Alfonso el Onceno, B.A.E., pp. 173-174.

${ }_{93}$ AHP. Ávila. Secc. Ayuntamiento, Leg. 5, nำ1. Edt. BARRIOS GARCÍA, A., CASADO QUINTANILLA, B., LUIS LÓPEZ, C. y SER QUIJANO, G. del., «Documentación del Archivo Municipal de Ávila (1256-1474)», Fuentes históricas abulenses I. Institución «Gran Duque de Alba», Ávila, 1988, doc. 1, pp. 13-19.

94 AM. Ávila. Secc. Históricos, Leg. 2, no 14, y AHP. Ávila. Secc. Ayuntamiento, Caja 15, Leg.4, no 15. BARRIOS GARCÍA, et alii., «Documentación del Archivo Municipal de Ávila...», Op. cit. doc. 2, pp. $20-26$.

${ }_{95}$ AM. Ávila. Secc. Históricos, Leg. 2, no 14, y AHP. Ávila. Secc. Ayuntamiento, Caja 15, Leg.4, no 15. BARRIOS GARCÍA, et alii., «Documentación del Archivo Municipal de Ávila...», Op. cit. doc. 3, pp. 26-28.

96 MONSALVO ANTÓN, J. Mª.., «El realengo y sus estructuras...», Op. cit. 107-109. 
caballería villana genérica y abierta a las exenciones y cargos públicos con tan sólo reunir una serie de requisitos formales. Por lo tanto, se podría afirmar que los caballeros villanos no se corresponden con los caballeros serranos, los cuales se reafirman según la Crónica de Ávila como superiores a aquéllos. Así, la vieja aristocracia local se corresponde con los caballeros serranos, siendo más tarde incorporados al privilegio jurídico, pero con menor entidad, los caballeros castellanos, por lo que no hay que confundir con el grupo hegemónico de la ciudad, ya que los serranos detentaban la preeminencia social por encima de aquéllos. El ascenso social de ciertos caballeros urbanos a la nueva nobleza, como el caso de nuestro personaje, Esteban Domingo, perteneciente a una de las ramas de los Dávila, muestra claramente que se encontraba en la cima de la jerarquía social, no perteneciendo a una incipiente caballería estamental establecida por el monarca, sino a una clase superior y más antigua conformada en linajes, que formó parte de la repoblación inicial de la zona.

De todas formas, la creación de esta caballería villana estandarizada por parte del monarca, responde a su intención de establecer una unidad jurídica aminorando las desigualdades sociales que habían impuesto el grupo hegemónico de los serranos. Sea como fuere, los caballeros abulenses desde la concesión de privilegio real se encuentran capacitados para cobrar montazgos y adehesar terrenos. El control ejercido en el concejo urbano les permite deslindar términos de aldea, pudiendo reservarse espacios de paso y de monte, los cuales posteriormente aprovecharán como espacios ganaderos. Como lo muestra el hecho de que por mandato expreso de Alfonso $\mathrm{X}$ se deslinden por parte de ciertos caballeros diversas zonas del territorio abulense a fin de evitar su despoblación ${ }^{97}$.

El proceso modificador de estructuración territorial en las zonas meridionales y serranas abulenses estuvo dirigido por un nuevo poblamiento o repoblación tardía, donde el concejo urbano hubo de volcarse hacia el interior de su propio término, en el cual, los grupos dirigentes, la caballería villana, bien desde el control de las instituciones concejiles, bien de forma particular a través de la obtención de privilegios y exenciones por parte del monarca, se aseguró el reparto jerarquizado y competitivo de la renta social ${ }^{98}$. Así, el proceso repoblador unió la exacción de tributos en un espacio territorial delimitado a la situación privilegiada que presentaba el orden caballeresco, y que junto al constante intento de ampliación de esa exención consolidaba la hegemonía de este grupo social. La nueva estructuración territorial supuso que los valles serranos del alfoz meridional abulense fueran ocupados en estas décadas de la segunda mitad del siglo XIII. De manera definitiva fue ocupado el curso alto del río Alberche mediante la segregación de términos de realengo por iniciativa del concejo o por concesión regia a un particular, creándose nuevos núcleos o pequeños señoríos, persiguiendo este

${ }_{97}$ AHP. Ávila. Secc. Ayuntamiento. Caja 27. Leg. 1, no 6-7-10; y AM. Ávila. Secc. Fincas y Bienes. Leg. 1. BARRIOS GARCÍA, A., et alii., «Documentación del Archivo Municipal de Ávila...» doc. 4-5-6-7-8-9, pp. 29-35.

98 BARRIOS GARCÍA, A., «Poder y espacio social...», Op. cit. pg. 240. 
proceso colonizador tardío un objetivo: la ocupación permanente de espacios deshabitados que presentaban un favorable aprovechamiento ganadero y el control de las rutas de paso obligado de ganado trashumante siendo beneficiarios de los ingresos que podía reportar. En definitiva, supuso el control del espacio con el fin de establecer nuevas fuentes de ingresos.

Sin embargo, la alternativa económica ofrecida significó el inicio de la conflictividad social, pues establecido el señor en el señorío pretendió para conseguir el aumento de sus rentas atraer población a su territorio mediante rebajas fiscales, como ya se apuntó, provocando el abandono de población desde los lugares de procedencia, bien desde la jurisdicción concejil, bien desde cercanos señoríos, iniciando el conflicto dentro del grupo hegemónico, lo que se había pretendido evitar permitiendo la creación de los mismos señoríos en detrimento de tierras y rentas de la jurisdicción del concejo urbano. No debemos olvidar el caso de numerosas aldeas substraídas a la jurisdicción concejil para convertirse en centros señoriales, que mediante la exención de «pechos» procuraban la atracción de población, generando reacciones incluso militares por parte del antiguo concejo urbano ${ }^{99}$.

Cambios que pueden relacionarse con las situaciones de violencia de los privilegiados, con la organización de éstos en linajes, con actos de usurpación de territorios comunales, con intentos de control de rutas ganaderas trashumantes, con la constitución de hermandades concejiles, con la aparición de señoríos individuales donados a estos caballeros villanos, y por último, con el inicio de la institución de mayorazgo como modo de vinculación de rentas. Cuando con el tiempo estas situaciones se consoliden y sean endémicas en la zona, ya avanzando el siglo XIV, se producirá la crisis y desestructuración del sistema, afectando a la redistribución de las rentas mediante el bloqueo de la producción y el reparto jerarquizado de la misma, aumentando la desigualdad social. La crisis de rentas y la persistente crisis agraria generada por la presión fiscal y las limitaciones legales, acabaron por impedir el crecimiento económico y la consecución de excedentes necesarios con que poder afrontar los tributos exigidos, originando graves desequilibrios sociales que generaron a su vez una conflictividad. No obstante, otro tipo de crisis generada por una climatología adversa había comenzado desde la segunda mitad del siglo XIII: en 1253 se constata una crisis de subsistencia en Burgos, aunque no se evidencia en tierra abulense, pero sí queda reflejada en las Cortes de Jerez de 1268; en 1282 el infante Sancho concede privilegios al monasterio de San Clemente de Ávila por la falta de pan y vino; en 1303 las tierras de Fontiveros y La Coja se conformaban como arenales improductivos por el crecimiento de las aguas; en las mismas fechas se constata una subida de precios agrícolas provocando el crecimiento de la inflación; y por último la crónica de

99 Oropesa arrasada por las milicias abulenses en 1307; el concejo de Alba de Tormes en 1294 compró al rey la villa de Santiago de la Puebla; el concejo salmantino hizo lo mismo con el castillo de Carpio Bernardo en 1313; BARRIOS GARCÍA, A., «Poder y espacio social...», Op. cit. pg. 250. 
Fernando IV nos informa en el año 1301 sobre la mortandad y el hambre que asoló el reino ${ }^{100}$. La incidencia de éstas y otras crisis alimenticias, constatadas en la documentación referida, provocaron la desestructuración del sistema productivo, y generaron a su vez la crisis de rentas y agraria ya apuntada, alcanzando con el tiempo las consecuencias señaladas.

Pero, lo que en definitiva determinaba la estructuración poblacional en el territorio no era la lucha por la escasez de espacios desocupados, sino el deseo o necesidad de tierras provocado por los impedimentos sociales y físicos derivados de los derechos feudales de propiedad. Los deslindes, citados anteriormente, realizados por caballeros abulenses, muestran a manera de ejemplo cómo los habitantes de estos lugares por falta de tierras para labrar no podían mantenerse y cumplir con las cargas fiscales, por lo que atendiendo a su posible abandono del lugar, los citados caballeros con plena potestad, previa concesión real, se ocupan de otorgar tierras a diversos concejos -El Hoyo, La Adrada, Manjabálago y Burgohondo, aldeas de Ávila- siendo posteriormente confirmados por el rey: «los omes buenos de los pueblos vinieron a él e mostráronle de cónmo algunas aldeas heran muy menguadas de heredad en que labrasen por pan, e pydiéronle por merçed que les mandase dar lugares en que cogiesen pan...»; ${ }^{101}$.

Para terminar, en cuanto al reparto poblacional en la zona, podemos concluir que los desplazamientos se producían de unas aldeas a otras, desde aldeas antiguas a las recién creadas, desde el realengo al señorío, y desde ciertos señoríos a otros, buscando beneficios económicos y exenciones fiscales, no pudiendo concretar que la despoblación de la Extremadura castellana sea un fenómeno de esta época.

\section{CONCLUSIONES}

Las disquisiciones expuestas sobre el análisis conceptual que hemos llevado a cabo, en general y en esta zona en particular, ponen de manifiesto la compleja realidad que conforma el régimen señorial, poniendo de relieve la falta de uniformidad formal de la potestad señorial, pues su configuración y el grado jurisdiccional que posea, depende del momento de su fundación y de los condicionamientos políticos, sociales y económicos como acontecimientos históricos, siendo causa y consecuencia el ritmo con que se lleve a cabo la repoblación y la potestad jurisdiccional del señor. Tales condicionantes dispondrán el grado de jurisdicción que conforma un señorío, alcanzando la diferenciación establecida por Salvador de Moxó con la concurrencia o no de facultades administrativas, fiscales y

100 BARRIOS GARCÍA, A., Estructuras agrarias... Op. cit. pp. 110-111.

101 AHP. Ávila. Secc. Ayuntamiento. Caja 27. Leg. 1, no 6-7-10; y AM. Ávila. Secc. Fincas y Bienes. Leg. 1. BARRIOS GARCÍA, A. et alii., «Documentación del Archivo Municipal de Ávila...», no 1, doc. 4-5-6-7-8-9, pp. 29-35. 
judiciales, del señorío solariego o territorial — cuyo elemento principal lo conforma el dominio sobre la tierra - y el señorío jurisdiccional pleno, en el que se dan, además del domino sobre la tierra, la facultad de juzgar, la potestad sobre los moradores y los derechos tributarios ${ }^{102}$. Señorío jurisdiccional que alcanzará su plenitud con los Trastámara, pero que iniciará su proceso ya en la $2^{\underline{a}}$ mitad del siglo XIII, época en que desde el dominio de solariego, imperan ciertas atribuciones jurisdiccionales ya enunciadas en los diplomas, para culminar en el Ordenamiento de Alcalá de 1348, el cual legitima por prescripción adquisitiva muchas jurisdicciones señoriales ${ }^{103}$. Sin embargo, el conocimiento de los diversos elementos que componen el señorío no debe hacernos olvidar la verdadera esencia del régimen señorial, régimen enfocado hacia el aprovechamiento económico y el control de rentas. Pero mejor utilizar las palabras de Moreno Núñez «El complejo jurisdiccional no es otra cosa que un instrumento en manos de los señores para asegurarse la percepción de todo tipo de rentas y tributos, incluidos los dimanantes de la potestad jurisdiccional, que deviene así en una verdadera superestructura a nivel señorial, cuyo fin primordial es consolidar y mantener la situación económica y social privilegiada de esa aristocracia feudal» ${ }^{104}$. Premisa que corrobora la posterior constitución de mayorazgo al establecer la sucesión hereditaria del señorío, vinculando el aprovechamiento de las rentas del mismo, como hemos visto.

Pues bien, el otorgamiento de derechos regios a un particular por necesidades de repoblación, o en otra índole, por pertenecer e incluirse en el juego de reparto de poderes a un estamento privilegiado en el marco de una sociedad desigual, tanto de hecho como de derecho, o de otro modo, obligado por la vigencia de un sistema social privilegiado, supuso el inicio de un proceso de estructuración territorial en las zonas meridionales y serranas abulenses. ¿Necesidades repobladoras, necesidades de unificación jurídica del reino, o presiones de los caballeros que controlaban las instituciones concejiles y municipales en una búsqueda de nuevas o alternativas opciones económicas?, es decir, ¿un proceso repoblador cuya finalidad preferentemente fiscal se encuadra en el marco de las tensiones sociales ya apuntadas entre el estamento hegemónico?. La respuesta quizá sea la unión de todas las premisas expuestas. La necesidad repobladora de la zona era evidente, pero la intención del rey por establecer una unificación jurídica en el reino puede haber llevado a acometer tales hechos sirviéndose de los caballeros para poder resolver tanto un problema como otro, además de así acallar un posible descontento que no interesaba al poder real y que era fruto de la competitividad generada entre el estamento privilegiado; en otro orden, cabe suponer el interés económico de este grupo que, a través de la repoblación tardía, buscaba nuevas rentas. En suma, de una u otra forma, los problemas no eran aislados y se constituían como una unidad que requería una respuesta glo-

102 MOXÓ, S. de., «Los señoríos: cuestiones metodológicas que plantea su estudio». Separata de AHDE, 1973, pp. 276 y ss.

103 Ordenamiento de Alcalá, Ley III, tit. XVII.

104 MORENO NÚÑ̃EZ., Ávila y su Tierra..., Op. cit. pg. 106. 
bal. Así, Alfonso X necesitaba para poder ejercer un control sobre su reino el establecimiento de una normativa jurídica unificada en todo el territorio y que le confirmara con una autoridad ejecutiva plena; al tiempo se requería un poblamiento efectivo del mismo para beneficio de la cámara regia, a lo que respondió ayudándose del grupo caballeresco, que para buscar el mantenimiento de su economía en serio detrimento por el alejamiento de la guerra, supo encauzarlo de una forma útil, reportándoles beneficios económicos y jurisdiccionales, suponiendo un pilar básico del fortalecimiento de la caballería villana, y consiguiendo al tiempo acallar posibles descontentos, es decir, resolver una serie de tensiones sociales provocadas en el seno de la elite caballeresca en su afán competitivo por el control de rentas, amén de tratar de solventar sus propios problemas con la nobleza, lo cual no consiguió, pues desencadenó la insurrección de ésta y de las ciudades apoyando al infante don Sancho.

Por lo tanto, bien por el apoyo del monarca interesado en la ocupación efectiva de estas zonas, bien por la influencia de la clase privilegiada que controlaba las instituciones municipales interesada en el aumento de sus rentas, bien por interés del concejo para repoblar las zonas aún vacías dentro de su término jurisdiccional, y seguramente por la unión de todas las interrogantes mencionadas, se llevó a cabo la repoblación tardía de este territorio.

En resumen y concluyendo el análisis, podemos partir con este ejemplo, en el cual Esteban Domingo, perteneciente al estamento caballeresco desde la condición inicial de nobleza local de carácter militar y agrario, rebasa su condición integrándose dentro de la esfera señorial en el marco de la repoblación, y confluyendo de forma particular en el fenómeno general del siglo XIII, el auge caballeresco, la repoblación rural y el incremento de los señoríos. Estas necesidades repobladoras, la «repoblación tardía», fueron en parte propulsadas por la monarquía, mediante la fundación de nuevas pueblas por Alfonso X, lo que desencadenó la revuelta nobiliaria de 1272 por parte del infante Don Sancho ${ }^{105}$. La repoblación interior, en suma, no pudo llevarla acabo el monarca en ocasiones de manera directa, por lo que se ayudó de ciertas instituciones y particulares, según los casos. Los concejos fueron inicialmente desde el siglo XII los artífices de la repoblación dentro de su término, pero la dificultad de la tarea y el ascenso nobiliario observado en dicha centuria, promovió el ascenso y participación de la oligarquía caballeresca, agotada la repoblación concejil. Pronto las necesidades repobladoras se conjugaron con las apetencias personales de esta oligarquía, mientras, el monarca apoyará la iniciativa otorgando mercedes y donaciones a sus servidores por los servicios prestados, consiguiendo una doble finalidad, el apoyo de esta oligarquía y la colonización de zonas yermas. Así, Esteban Domingo, a sus obligaciones militares y el ejercicio del cargo de juez del rey, unirá otras

105 MOXÓ, S. de., El auge de la nobleza urbana de Castilla y su proyección en el ámbito administrativo y rural a comienzos de la Baja Edad Media (1270-1370). Real Academia de la Historia, t. CLXXVIII, Madrid, 1981, pg. 417. 
en el municipio y la iglesia abulense, que junto a las franquicias y libertades propias de los caballeros de Ávila, otorgadas en las mismas fechas que la concesión del señorío, consolidará su posición dominante en el patriciado urbano.

En este marco se encuadra la concesión real de señorío jurisdiccional a Esteban Domingo, no suponiendo un acto en exclusiva, sino que pertenece a un proceso generalizado en toda la zona al sur del Duero, donde los condicionantes en los distintos territorios eran semejantes. Por otro lado, la dificultad de la repoblación explica en parte la concesión de exenciones regias, tanto fiscales como judiciales, otorgada a Esteban Domingo para ejercerla sobre sus vasallos, suponiendo un signo de protección a éste en su actividad repobladora, favoreciendo el desarrollo de su señorío jurisdiccional.

Por lo tanto, la concesión de privilegio a Esteban Domingo queda enmarcada en un conflicto general que responde, por un lado, a necesidades de estructuración del reino, y por otro, a la búsqueda de una alternativa económica por la caballería villana; conflicto que quedó resuelto momentáneamente por la repoblación tardía de las zonas serranas y de escasa población, que permitió a los beneficiarios la acumulación de rentas mediante el control del ganado y las rutas trashumantes. Y lo que llama la atención resultando paradójico es que las necesidades por parte de la realeza de articular el territorio con un enfoque económico y tributario, terminaran en la entrega a particulares, erigidos en rectores de la política concejil, de una serie de privilegios territoriales y jurisdiccionales, a consecuencia del encumbramiento político que alcanzaron como grupo hegemónico reservándose los cargos que dirimían las directrices municipales de la ciudad. 


\section{ANEXO DOCUMENTAL}

\section{DOCUMENTO № 1}

1256, abril, 26. Soria.

Alfonso X concede a Esteban Domingo, alcalde del rey, el lugar de Villafranca con todo su término, para que realice su repoblación o lo que quisiere, exceptuando la «moneda forera».

A. ADM. Secc. Villafranca, Leg. 1, doc. 1.

B. ADM. Secc. Villafranca, Leg. 1, doc. 2 (en traslado de 1707).

Ed. MOZO CILLERO, C. Villafranca de la Sierra, sus hombres y sus tierras. Ávila, 2001, pp. 35-37.

Ed. LUIS LÓPEZ, Carmelo, "Otros señoríos de los sectores central y septentrional», en Historia de Ávila IV, Edad Media (S. XIV-XV), Ávila, Institución «Gran Duque de Alba», 2009, pp. 262-263.

\section{DOCUMENTO № 2}

1256, agosto, 25. Villafranca de la Sierra.

Esteban Domingo de Ávila, alcalde del rey, otorga una carta puebla a Villafranca, estableciendo los límites territoriales, la fiscalidad a seguir, la cuestión de la justicia a aplicar por la comisión de determinados delitos, y por último, determina las condiciones de sucesión en el señorío.

B. ARCHV, Pergaminos, Carp. 17, doc. 9. (Inserto en 30-IV-1350)

B. ADM. Secc. Villafranca, Leg. 1, Doc. 2. (Traslado del siglo XVI)

C. ADM. Secc. Villafranca, Leg. 1, Doc. 2. (Traslado del siglo XVIII)

Ed. TELLERÍA ORBELZU, A. Maㅡ. «El señorío de Villafranca de la Sierra en Ávila: dos diplomas medievales en el Archivo de la Real Chancillería de Valladolid", en Edad Media 2001, pp. 230-232.

Ed. en parte por LUIS LÓPEZ, Carmelo, «Otros señoríos de los sectores central y septentrional», en Historia de Ávila IV, Edad Media (S. XIV-XV), Ávila, Institución «Gran Duque de Alba», 2009, pg. 266.

\section{DOCUMENTO № 3}

1260, mayo, 25. Villafranca de la Sierra.

Blasco Muñoz, hijo de Esteban Domingo, confirma la carta puebla otorgada por su padre al lugar de Villafranca, como heredero y señor del mismo. 
B. ARCHV, Pergaminos, Carp. 17, doc. 9. (Traslado inserto en 30-IV-1350)

B. ADM. Secc. Villafranca, Leg. 1, Doc. 2. (Traslado del siglo XVIII)

Ed. TELLERÍA ORBELZU, A. Mํㅡ. «El señorío de Villafranca de la Sierra en Ávila: dos diplomas medievales en el Archivo de la Real Chancillería de Valladolid", en Edad Media 2001, pp. 230-232.

Ed. en parte por LUIS LÓPEZ, Carmelo, «Otros señoríos de los sectores central y septentrional», en Historia de Ávila IV, Edad Media (S. XIV-XV), Ávila, Institución «Gran Duque de Alba», 2009, pg. 272.

\section{DOCUMENTO № 4}

1277, septiembre, 23. Burgos.

Confirmación de Alfonso X de la sentencia que dio el alcalde de la Mesta Rui Fernández, en 16 de mayo de dicha año, por la que declara que el término de Villafranca es dehesa de labor.

A. ADM. Sección de Villafranca, Leg. 1, Doc. 3

Sepan quantos esta carta vieren cómo yo, don Alfonso por la graçia de Dios, rey de Castilla, de Toledo, de León, de Gallizia, de Seuilla, de Córdoua, de Murçia, de lahén e del Algarbe, vi carta fecha en esta manera:

Sepan quantos esta carta uieren cónmo yo, Roy Fernández de Sant Fagund, vasallo del rey e (et) entregador delos pastores et dador de las defesas por el rey, vin (sic) a Villafranca sobre querella que me dieron los pastores que teníen mayores defesas que non deuíen tener. Et yo uí el logar de la defesa que comiença por somo de los Foyos del Azeueda así conmo parten con los de Piedrafita e uierten las aguas a Corneia; et por somo del Çerbunal Longuiello así como uierten las aguas a Corneia; et por somo de los Foyos de Uelacha así conmo uierten las aguas a Corneia; et por somo del Puerto de Uechía así como uierten las aguas a Corneia; et por somo del Val de Serrota así como uierten las aguas a Corneia; et por somo de la Garganta del Uelesar conmo uierten las aguas a Corneia; et por somo de Val de Pasqual Munnoz conmo uierten las aguas a Corneia; et por somo de Maiada [de] Lança conmo uierten las aguas de Corneia; et por [somo] del Fortigal como uierten las aguas a Corneia; et por somo del Soto del Puerto de Sanchánder e por la carrera ayuso conmo da en las casas de don Viçeynte e conmo parten con Naualuenga.

Et segund los bueyes que ay en Villafranca, fallé que no teníen mayor defesa de conmo manda el rey, de cada yugo de bueyes tres arançadas. Et yo otorguégelo, quelo tengan por defesa por estos logares sobredichos.

Et porque esto sea más firme, doles esta carta seellada con mío seello en testimonio. 
Fecha la carta XVI días de mayo, era de mill e CCC e quinze años.

Et Velasco Munnoz, mío alcalde, pidiome merçed quele mandase dar mi carta de confirmamiento pora en todo tienpo. Et yo tóuelo por bien.

Et mando e defiendo que ninguno non sea osado de paçer nin de cortar sin su mandado a destos sus uasallos en estos logares sobredichos, ca qualquier quelo fiziese pecharíe a ellos el danno doblado, e a mí çient marauedís en pena.

Dada en Burgos XXIII días de setenbre, era de mill e CCC e quinze annos.

Yo Roy Munnoz la fiz escreuir por mandado del rey.

\section{DOCUMENTO № 5}

1302, junio, 26. Medina del Campo

Fernando IV confirma a Esteban Domingo de Ávila, alcalde del rey, los privilegios dados por su abuelo, Alfonso X, por su padre, Sancho IV, y por él mismo, por cuanto resultaba de la población que hizo Esteban Domingo de Ávila, su abuelo, en Villafranca, con declaración de no pertenecer ni a él ni a sus progenitores, derechos, pechos ni justicia en Villafranca, y si moneda forera le pertenecía, hacia gracia de ella a Esteban Domingo, nieto del dicho Esteban Domingo.

A. ADM. Secc. Villafranca, Leg. 1, Doc. 4

B. ADM. Secc. Villafranca, Leg. 1, Doc. 2. (Traslado del siglo XVIII)

Ed. MOZO CILLERO, C. Villafranca de la Sierra, sus hombres y sus tierras. Ávila, 2001, pp. 37-38.

Ed. en parte por LUIS LÓPEZ, Carmelo, «Otros señoríos de los sectores central y septentrional», en Historia de Ávila IV, Edad Media (S. XIV-XV), Ávila, Institución «Gran Duque de Alba», 2009, pg. 275.

\section{DOCUMENTO № 6}

1313, septiembre, 19.

El infante don Pedro, hijo del rey don Sancho IV, y tutor con la reina doña María de Molina, su madre, del rey Alfonso XI, su sobrino, confirma a Blasco Muñoz, hijo de Esteban Domingo de Ávila, la villa de Villafranca de Valdecorneja y las casas con su torre que están en la Rúa de los Caballeros en Ávila, que pertenecieron a Esteban Domingo su abuelo y posteriormente a su padre, con vasallos, pechos, derechos y pertenencias.

A. ADM. Secc. Villafranca, Leg. 1, Doc. 5.

B. ADM. Secc. Villafranca, Leg. 1, Doc. 2. (Traslado del siglo XVIII) 
Sepan quantos esta carta vieren, cónmo yo, infante don Pedro, fijo del muy noble rey don Sancho e tutor con la reyna doña María, mi madre, del rey Alfonso, mío sobrino, e guarda de sus regnos, catando quantos seruiçios la reyna doña María, mi madre, e yo reçebiemos de uos, Blasco Munnoz, fijo de Esteuan Domingo de Áuila, e de aquéllos onde vos venides. E porque fallamos e tenemos que deuedes auer con derecho Villafranca, que es en Val de Corneia, e las casas de la torre que son en Áuila en la Rúa de los Caualleros, la qual Villafranca e las dichas casas fue todo de Esteuan Domingo, uuestro auuelo e de Esteuan Domingo uuestro padre, pongo convusco de uos apoderar e entregar las dichas casas e la dicha Villafranca con todos los vasallos e pechos e derechos e con todas sus pertenençias, quelas ayades daquí adelante para sienpre jamás, vos e vuestros herederos o aquél o aquéllos a quien lo vos ordenardes o mandáredes quelo aya. E a defender uos en la tenençia a uos o a quien por vos lo ouiere, e de uos lo non tirar en ninguna manera en quanto durare el poder de Áuila en la reyna doña María, mi madre, e en mí, o en qualquier de nos, quier por tutoría o en otra manera qualquier.

Et esta entrega e apoderamiento pongo conuusco de uos fazer en la manera que dicha es, del día que esta carta es fecha fasta quarto día en manera quelo ayades todo esto que dicho es, tan bien e tan cunplidamiente para sienpre jamás por juro de heredat, para fazer dello e en ello e sobrello lo que quesiéredes e por bien touiéredes, así conmo el que más conplidamiente lo ouo de aquéllos quelo ouieron fasta agora.

Et otrosí, de uos dar carta o cartas, las que fueren menester, del rey don Alfonso, mío sobrino, cuyo tutor yo so, e mías, para que todo esto que dicho es vos sea guardado e mantenido en la manera que sobredicha es, para en todo tienpo a uos o a quien por vos lo ouiere. Et para tener e guardar e conplir todo esto que sobredicho es, e para defender vos en la tenençia de la dicha Villafranca e de las casas dichas con todos sus usos e sus pertenençias de todos aquéllos que vos lo enbargaren o uos lo contrallaren todo esto que sobredicho es o algo dello, así por fuerça conmo por pleito, conmo por otra manera qualquier que sea que uos lo quesieren enbargar. Et para non uos lo tirar, fago vos segurança buena e verdadera, e prometo vos lo así a buena fe sin mal engaño, e júrolo a Dios de lo conplir e de lo guardar todo así, segunt dicho es. Et si todo esto non uos lo mantouiere conmo dicho es, que uos e los uuestros parientes e todos aquéllos que por uos e por ellos o por qualquier dellos ouieren a fazer, que podades tomar otro tutor 0 otros tutores, qualquier o qualesquier que uos e aquéllos que fueren a vuestra boz quesiéredes. Et que podades sin mal estança catar quien vos defienda e non seades tenudos de fazer por mí conmo por tutor.

Et desto vos mando dar esta mi carta seellada con mío seello de çera colgado.

Fecha XIX días de septienbre, era de mil e trezientos e çinquenta e un annos. (Sello de cera pendiente). 


\section{DOCUMENTO № 7}

1313, septiembre, 21. Ávila.

La reina doña María de Molina, tutora junto al infante don Pedro, su hijo, del rey Alfonso XI, su nieto, confirma a Blasco Muñoz, hijo de Esteban Domingo de Ávila, la villa de Villafranca de Valdecorneja y las casas con su torre que están en la Rúa de los Caballeros en Ávila, que pertenecieron a Esteban Domingo, su abuelo, y después a Esteban Domingo, su padre, con vasallos, pechos, derechos y pertenencias, en remuneración por servicios prestados.
A. ADM. Secc. Villafranca, Leg. 1, Doc.5.
B. ADM. Secc. Villafranca, Leg. 1, Doc.5 (Traslado de fecha 15 de marzo de 1479).
B. ADM. Secc. Villafranca, Leg. 1, Doc. 2. (Traslado del siglo XVIII)

Sepan quantos esta carta vieren cónmo yo doña María por la graçia de Dios, reyna de Castiella e de León e sennora de Molina, e tutor con el infante don Pedro mi fiio, del rey don Alfonso, mío nieto, e guarda de sus regnos.

Catando quantos seruiçios yo e el infante don Pedro reçebimos de vos Blasco Munnoz, fiio de Esteuan Domingo de Áuila e de aquellos onde uos venides, e porque fallamos e tenemos que deuedes auer con derecho Villafranca, que es en Val de Corneia, e las casas de la torre que son en Áuila en la Rúa de los Caualleros. La qual Villafranca e las dichas casas fue todo de Esteuan Domingo, uuestro auuelo e de Esteuan Domingo, uuestro padre. Pongo convusco de uos apoderar e entregar las dichas casas e la dicha Villafranca con todos los vasallos e pechos e derechos, e con todas sus pertenençias, quelas ayades daquí adelante para sienpre jamás, vos e uuestros herederos, o aquél o aquéllos a quien lo uos ordenardes o mandardes quelo aya. Et a defender uos en la tenençia a uos o a quien por uos lo ouiere, e de uos lo non tirar en ninguna manera en quanto durare el poder de Áuila en mí e enel infante don Pedro o en qualquier de nos, quier por tutoría o en otra manera qualquier.

Et esta entrega e apoderamiento pongo convusco de uos fazer en la manera que sobredicho es del día que esta carta es fecha fasta quarto día, en manera quelo ayades todo ésto que dicho es tan bien e tan conplidamiente para sienpre jamás por juro de heredat, para fazer dello e en ello e sobrello lo que quesierdes e por bien touierdes, así conmo el que más conplidamiente lo ouo de aquéllos quelo ouieron fasta agora.

Et otrosí, de uos dar carta o cartas, las que uos fueren menester del rey don Alfonso, mío nieto, cuya tutor yo so, e mías, para que todo esto que dicho es, uos sea guardado e mantenido en la manera que sobredicho es para en todo tienpo, a uos o a quien por uos lo ouiere. Et para tener e guardar e conplir todo esto que sobredicho es, e para defender uos en la tenençia de la dicha Villafranca e de las casas dichas con todos sus usos e sus pertenençias de todos aquellos que uos 
lo enbargaren o vos lo contrallaren todo esto que sobredicho es o algo dello, así por fuerça conmo por pleyto conmo por otra manera qualquier que sea, que vos lo quesieren enbargar.

Et para non vos lo tirar, fago vos segurança buena e verdadera, e prometo uos lo así a buena fe sin mal engaño, e júrolo a Dios de lo conplir e de lo guardar todo así segunt dicho es. Et si todo esto non vos lo mantouiere conmo dicho es, que uos e los uuestros parientes e todos aquéllos que por uos e por ellos o por qualquier dellos ouieren a fazer, que podades tomar otro tutor o otros tutores, qualquier o qualesquier que uos e aquéllos que fueren a uuestra boz quesierdes, e que podades sin mal estança catar quien uos defienda, e non seades tenudos de fazer por mí conmo por tutor.

Et désto uos mando dar esta mi carta seellada con mío seello de çera colgado.

Fecha veynte e un días de setiembre, era de mill e trezientos e çinquenta e un annos.

(Sello de cera pendiente).

\section{DOCUMENTO № 8}

1313, septiembre, 21. Ávila.

Privilegio del rey Alfonso dado en Ávila a 21 de septiembre, era de 1351, para que los concejos de Ávila y Villafranca entregasen a Blasco Muñoz, hijo de Esteban Domingo, dicha villa de Villafranca, con todos sus vasallos, pechos, derechos pertenencias y casas de la torre de Ávila en la calle de los Caballeros, que eran suyos por muerte de su padre y se lo habían ocupado algunos parientes por haber quedado pequeño y sin edad cuando murió su padre.
A. ADM. Secc. Villafranca, Leg. 1, Doc. 18.
B. ADM. Secc. Villafranca, Leg. 1, Doc. 2. (Traslado del siglo XVIII)
B. ADM. Secc. Villafranca, Leg. 1, Doc. 8. (Copia impresa del siglo XVIII sobre
traslado inserto en fecha 1389, marzo, 19) (Resumen inserto del documento)
B. ARCHV. 1.1. Pergaminos, Carpeta, 17, 10. (Traslado inserto en fecha 1389, marzo, 19) (Resumen inserto del documento)

Don Alfonso por la graçia de Dios, rey de Castiella, de Toledo, de León, de Galizia, de Seuilla, de Córdoua, de Murçia, de lahén, del Algarbe e sennor de Molina.

Al conçeio de Áuila de villa e de aldeas e a los alcalldes tanbién de la villa conmo de la hermandat, e al alguazil que ý agora son o serán daquí adelante, o a qualquier o qualesquier dellos que esta mi carta vieren. Salut e graçia.

Sepades que porque fallé que Esteuan Domingo, padre de Blasco Munnoz, de ý de Áuila, teníe e auíe a Villafranca que es en Val de Corneia, e las casas 
dela torre que son en Áuila en la Rúa de los Caualleros, al tienpo que murío en seruiçio del rey don Sancho, mi auuelo que Dios perdone. Et que este dicho Blasco Munnoz, fincó su fijo mayor e heredero del dicho lugar de Villafranca e de las casas e de los otros bienes que su padre dexó, et porque fincó pequeño e $\sin$ edat e algunos sus parientes tomaron e entraron los dichos bienes conmo non deuíen, seyendo él pequeño conmo dicho es e non lo podiendo demandar fasta aquí, pidiome merçed quele fiçiese entregar el dicho lugar de Villafranca con sus pertenençias e las dichas casas conmo dicho es.

Et yo con acuerdo e con otorgamiento dela reyna doña María, mi auuela, e del infante don Pedro, mío tío, e míos tutores, por esto e por fazer bien e merçed al dicho Blasco Munnoz por los seruiçios que aquellos onde él viene fizieron a los reyes onde yo vengo, e él fizo e faze a mí, tengo por bien e mando que él cobre e aya el dicho lugar de Villafranca con todos sus derechos e las dichas casas conmo dicho es.

Porque uos mando luego vista esta mi carta a todos en uno e a qualquier de uos que para esto fuerdes llamados que ayudedes al dicho Blasco Munnoz a entregarse en las casas dichas e en el dicho lugar de Villafranca, con vasallos e derechos e usos e pertenençias, si el dicho Blasco Munnoz por sí fazer non lo pudiere, a quien dé poder por esta mi carta, que entre e tome las dichas casas e la dicha Villafranca con todos sus vasallos e pechos e derechos e con todas sus pertenençias, segunt quelo ouieron aquellos donde él viene que meior e más conplidamiente lo ouieron. Et mando so pena dela mi merçed al conçeio e a los omnes buenos de Villafranca e a los alcalldes del dicho lugar que reçiban al dicho Blasco Munnoz por su sennor, e quel[e] recudan con todos los derechos e pechos e con todas las otras pertenençias, segunt que más conplidamiente recudieron a los que ouieron el dicho lugar. Et si así fazer non lo quesieren, mando al dicho Blasco Munnoz queles tome los cuerpos e lo queles fallare fasta que gelo fagan así fazer. Et uos nin ellos non fagades ende ál, so pena de mill marauedís de la moneda nueua a cada uno.

Et si el conçeio e los omnes buenos del dicho lugar ouieren fecho pleyto o pleytos o reçebimiento fasta que por sí o por el dicho lugar a qualquier o qualesquier omnes que sean, yo gelo quito e los do ende por libres e por quitos daquí adelante cunpliendo ellos todo esto que yo mando al dicho Blasco Munnoz.

Et de cónmo uos e el conçeio [e] los omnes buenos de Villafranca cunplierdes esto que yo mando, mando a qualquier escriuano público que para esto fuere llamado que dé ende al dicho Blasco Munnoz un testimonio signado con su signo, por que yo sea çierto en cónmo cunplierdes mío mandado. Et non faga ende ál, so la pena sobredicha. La carta leída dátgela.

Dada en Áuila, veinte e un días de setienbre, era de mill e trezientos e çinquenta e un annos.

(Sello colgado) 
